\title{
Analysis of Pressure Data from the Horizontal Wells with Multiple Hydraulic Fractures in Shale Gas
}

\author{
Essa M. Tabar \\ West Virginia University
}

Follow this and additional works at: https://researchrepository.wvu.edu/etd

\section{Recommended Citation}

Tabar, Essa M., "Analysis of Pressure Data from the Horizontal Wells with Multiple Hydraulic Fractures in Shale Gas" (2011). Graduate Theses, Dissertations, and Problem Reports. 2265.

https://researchrepository.wvu.edu/etd/2265

This Thesis is protected by copyright and/or related rights. It has been brought to you by the The Research Repository @ WVU with permission from the rights-holder(s). You are free to use this Thesis in any way that is permitted by the copyright and related rights legislation that applies to your use. For other uses you must obtain permission from the rights-holder(s) directly, unless additional rights are indicated by a Creative Commons license in the record and/ or on the work itself. This Thesis has been accepted for inclusion in WVU Graduate Theses, Dissertations, and Problem Reports collection by an authorized administrator of The Research Repository @ WVU. For more information, please contact researchrepository@mail.wvu.edu. 


\title{
Analysis of Pressure Data from the Horizontal Wells with Multiple Hydraulic Fractures in Shale Gas
}

\author{
Essa M. Tabar \\ Thesis Submitted to the \\ Collage of Engineering and Mineral Resources at \\ West Virginia University \\ in partial fulfillment of the requirements for the degree of \\ Master of Science \\ in \\ Petroleum and Natural Gas Engineering
}

Khashayar Aminian, Ph.D. Chair

Ilkin Bilgesu, Ph.D.

Samuel Ameri, M.S.

Department of Petroleum and Natural Gas Engineering

Morgantown, West Virginia

2011

Keywords: Unconventional Gas Reservoir, Flow Regimes, Linear Flow Horizontal Wells, Hydraulic Fractures, Low Permeability.

Copyright 2011 Essa M. Tabar 


\section{ABSTRACT \\ Analysis of Pressure Data from the Horizontal Wells with Multiple \\ Hydraulic Fractures in Shale Gas}

Essa M. Tabar

In the last several years, the unconventional gas reservoirs development has grown tremendously. Most of these unconventional reservoirs have very low permeability and are not able to produce an economic flow rate without stimulation treatments. The common method to improve the production is by a horizontal well with multiple hydraulic fractures. Hydraulic fracturing is a stimulation practice to improve the permeability in order to obtain commercial production. Horizontal wells with multiple hydraulic fracture treatments have proven to be an effective method for development of unconventional reservoirs.

The objective of this study is to investigate the interpretation of pressure transient responses from horizontal wells with single and multiple hydraulic fractures using the commercial reservoir simulator. In addition, the research will focus on identifying the impact of the reservoir and fracture properties on the flow regimes of a horizontal well producing from the low permeability reservoirs.

The different flow regimes appear during horizontal-well transient flow. However, the existence of these flow regimes is closely associated with the dimensions of the half length of the fracture, fracture permeability, drainage area, horizontal well length, etc. Hence, it is common that some flow regimes are not present.

The impact of some of the reservoir parameters was analyzed. Drainage area, horizontal well length and reservoir permeability were found to have an impact on flow regimes. In addition to the reservoir parameters, a range of hydraulic fracture parameters was studied. The number of hydraulic fracture, fracture width and fracture half-length were found to have an impact on flow regimes. Fracture permeability and fracture porosity have no major impact on flow regimes. 


\section{ACKNOWLEDGMENTS}

I would like to thank my academic/research advisor, Dr. Kashy Aminian for his support and guidance during the course of this study. Professor Kashy has always been available to answer my questions.

I would also like to express my appreciation to Professor Sam Ameri and Dr. Ilkin Bilgesu for their guidance and advice during my study in Petroleum and Natural Gas Engineering. I also appreciate all of you for being a part of my committee.

I am very grateful to the staff of the Department of Petroleum and Natural Gas Engineering, because their courses have helped me a lot in this research.

Many thanks are due to the Libyan Ministry of Education and Scientific Research for providing me a scholarship. I am elated for this opportunity.

My special love goes to the person who will be so happy if she is alive; "My Mother" May Allah keeps her in the paradise.

My special thanks to my father who always supports and encourages me to be an excellent guy. I hope to always fill his expectations.

Sincere thanks are due to my friends in West Virginia University. I would like to express my special appreciation to Nordin, Abbas, A. Yousf, A. Aboseta, H. Abdusalam, O. Alhmouz, and Rakib. Finally, my deepest sincere appreciation goes to my brothers and sisters for their patience and kindness. 


\section{TABLE OF CONTENTS}

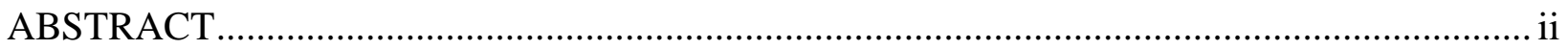

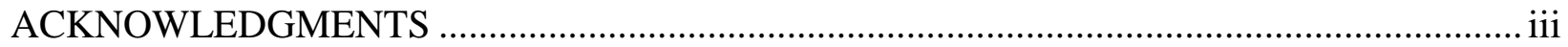

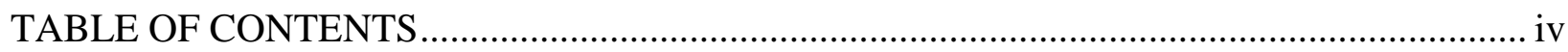

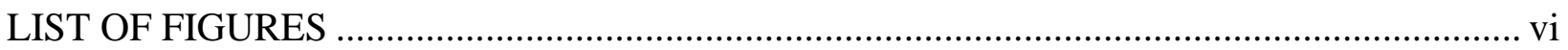

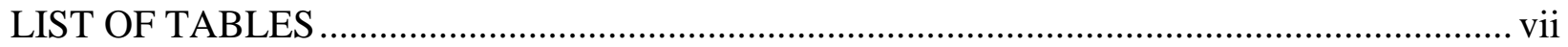

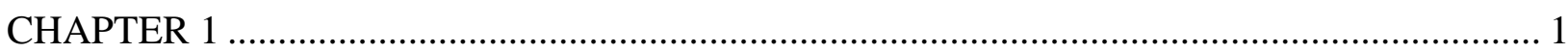

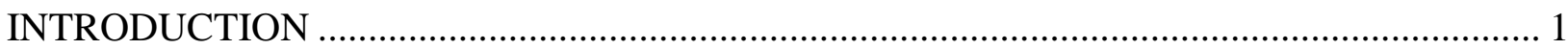

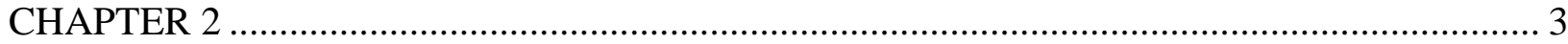

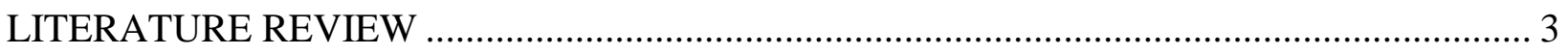

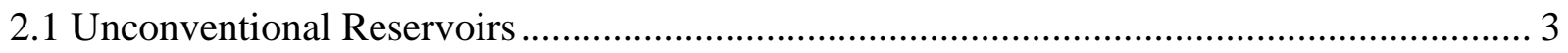

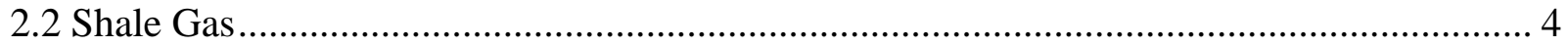

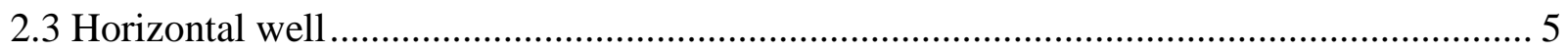

2.4 Hydraulic Fracturing of Horizontal Well ..................................................................... 8

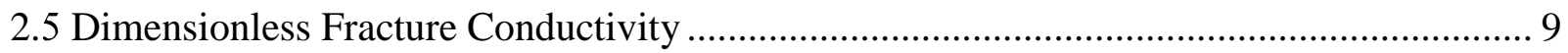

2.5.1 Infinite Conductivity Fracture ............................................................................... 10

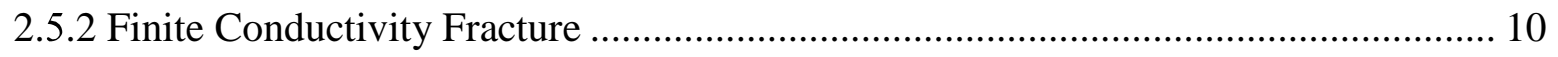

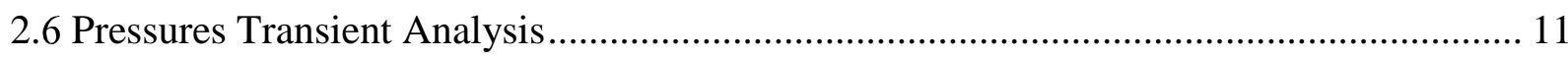

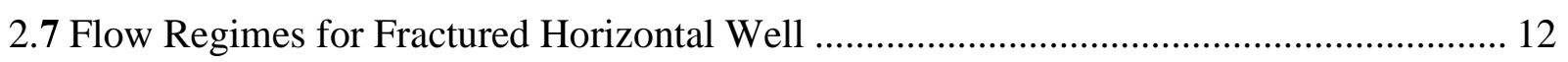

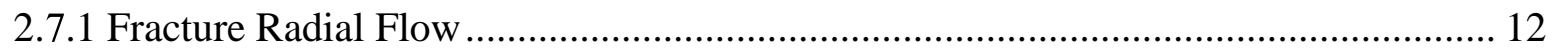

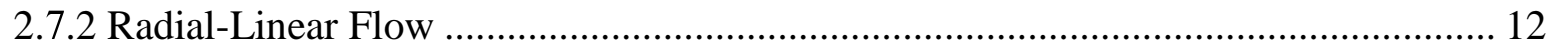

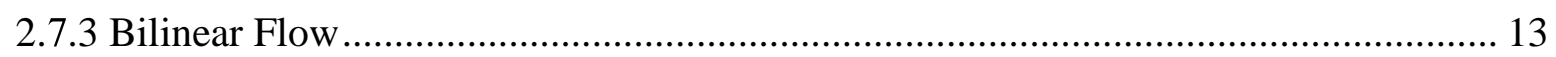

2.7.4 Formation Linear Flow........................................................................................ 13

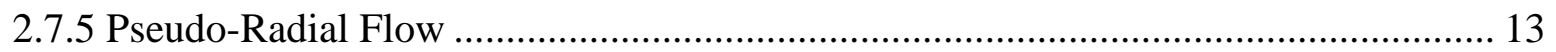

2.7.6 Compound Linear Flow (Trilinear Flow) .............................................................. 14

2.7.7 Compound Pseudoradial Flow ............................................................................. 14

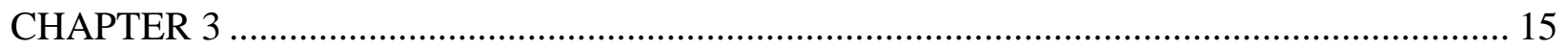

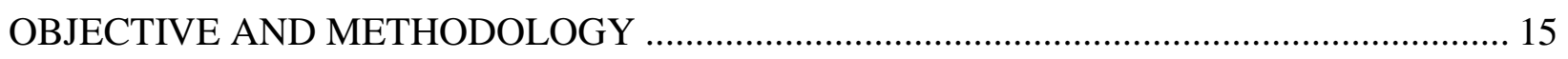

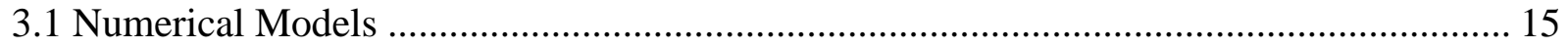

3.2 Base Model Parameters and Assumptions .................................................................... 15

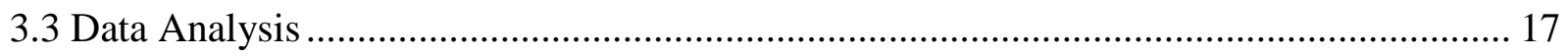




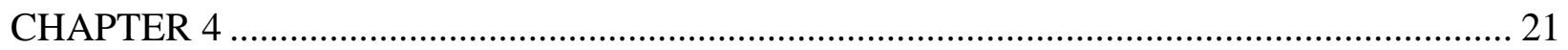

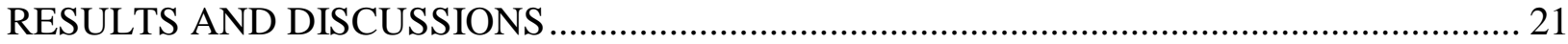

4.1 The Impact of the Number of Hydraulic Fractures on Flow Regimes. ........................ 21

4.2 The Impact of Reservoir Permeability on Flow Regimes ....................................... 22

4.3 The Impact of Fracture Width on Flow Regimes.................................................. 24

4.4 The Impact of Drainage Area and Horizontal Well Length on Flow Regimes .............. 26

4.5 The Impact of Fracture Permeability on Flow Regimes........................................... 29

4.6 The Impact of Fracture Half Length on Flow Regimes........................................... 30

4.7 The Impact of Fracture Porosity on Flow Regimes................................................ 32

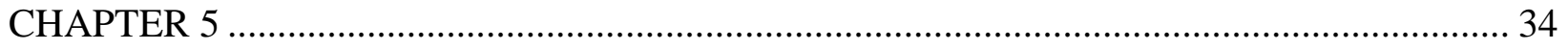

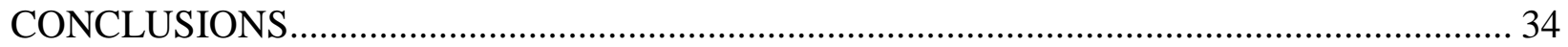

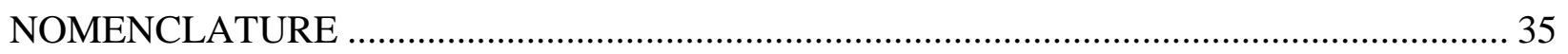

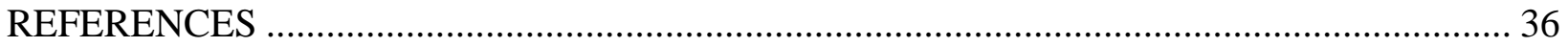




\section{LIST OF FIGURES}

Figure 1: The Resources triangle of both conventional and unconventional resources ................ 3

Figure 2: United States conventional and unconventional natural gas production...................... 4

Figure 3: Gas shale basins in the United States with estimated gas reserves ........................... 5

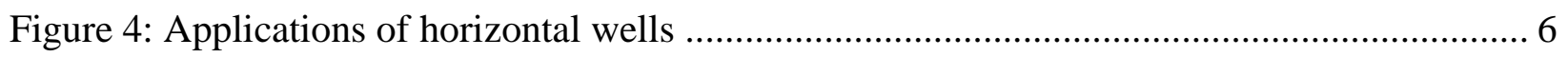

Figure 5: A horizontal well with vertical bedding planes ............................................... 8

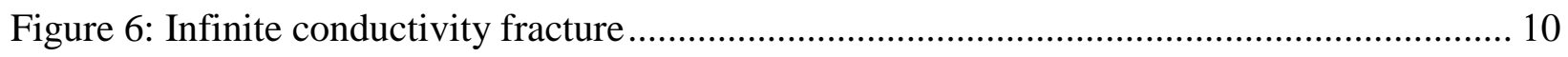

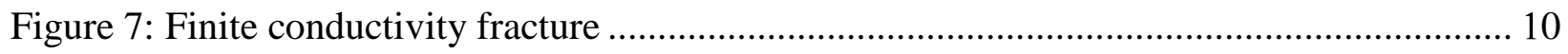

Figure 8: Flow regimes for fractured horizontal wells ................................................... 11

Figure 9: Trilinear flow regimes for multiple fractured horizontal well .................................. 14

Figure 10: A horizontal well model with a 4,000 ft by 2,000 ft and well length of 3,000 ft....... 19

Figure 11: A horizontal well model with 4,000 ft by $1000 \mathrm{ft}$ and well length of 4,000 ft......... 20

Figure 12: Five-point method for calculating the pressure derivative ...................................... 20

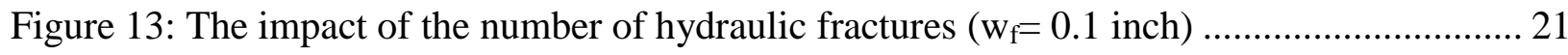

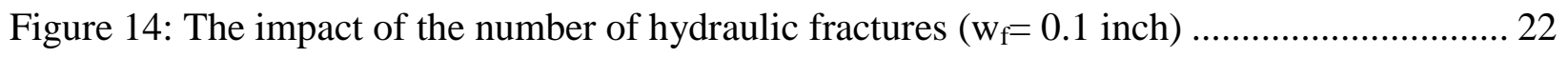

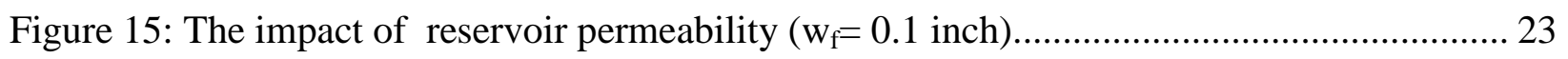

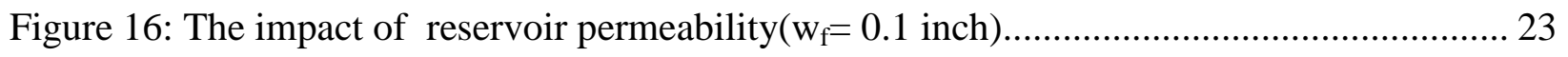

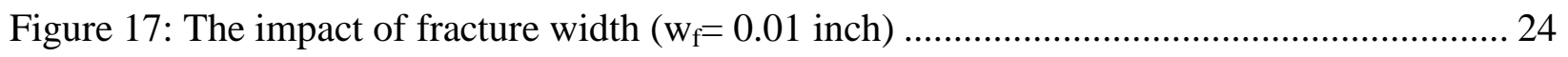

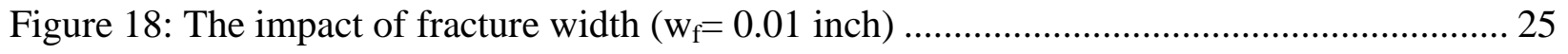

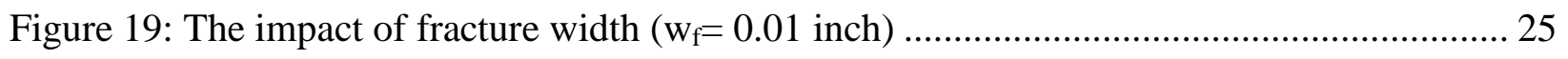

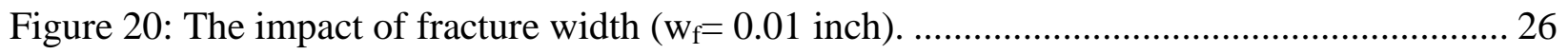

Figure 21: The mpact of the drainage area and horizontal well length $\left(\mathrm{w}_{\mathrm{f}}=0.1 \mathrm{inch}\right) \ldots \ldots \ldots \ldots \ldots \ldots \ldots . . . \ldots \ldots$

Figure 22: The impact of drainage area and horizontal well length $\left(\mathrm{w}_{\mathrm{f}}=0.1 \mathrm{inch}\right)$....................... 27

Figure 23: The impact of drainage area and horizontal well length $\left(\mathrm{w}_{\mathrm{f}}=0.1 \mathrm{inch}\right)$....................... 28

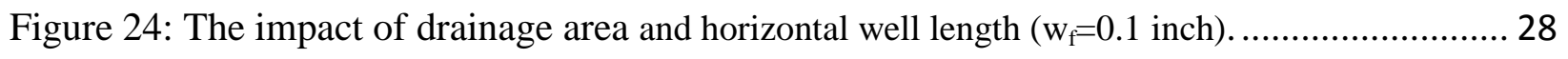

Figure 25: The impact of fracture permeability for 4 hydraulic fractures. ................................. 29

Figure 26: The impact of fracture permeability for 13 hydraulic fractures ............................. 30

Figure 27: The impact of fracture half length for 4 hydraulic fractures .................................. 31

Figure 28: The impact of fracture half length for 13 hydraulic fractures .................................. 31

Figure 29: The impact of fracture porosity for 4 hydraulic fractures ...................................... 32

Figure 30: The impact of fracture porosity for 13 hydraulic fractures ................................... 33 


\section{LIST OF TABLES}

Table 1: Comparison of data for gas shales in the United States............................7

Table 2: Parameters and values used in the base model. .................................... 18

Table 3: Ranges of values used in the model.......................................... 19 


\section{CHAPTER 1}

\section{INTRODUCTION}

Horizontal drilling with multiple hydraulic fracturing has recently become the key technology to achieve economic production from shale gas reservoirs. The hydraulic fracturing is a formation stimulation practice which is used to increase permeability in a formation. Horizontal drilling technology is widely used to increase drainage area and productivity of the low permeability reservoirs.

Pressure transient analysis is now commonly accepted for evaluating the well performance and reservoir characteristics. Pressure transient behavior of hydraulically fractured horizontal wells in tight formations is important for two reasons. First, pressure transient tests are instrumental to characterize both the reservoir and the hydraulic fractures. The complex interplay of horizontal well, hydraulic fractures, natural fractures, and a tight matrix complicates the interpretation of pressure transient responses. Therefore, for accurate interpretation of pressure transient tests, a thorough understanding of flow characteristics are essential. Second, the production of the hydraulically fractured horizontal wells in tight formations takes place under transient flow regimes for a long period. Therefore, the production performances of these wells are dominated by the characteristics of transient flow regime (Medeiros, F. et al, 2007).

In this research, a reservoir simulation model was constructed to identify the effect of the multiple hydraulic fractures on horizontal well flow regime in unconventional reservoirs. In addition, the impact of the reservoir and hydraulic fracture properties were investigated. 
The flow regimes can be characterized by the slope of the plot of pressure change and its derivative versus time on diagnostic plot. In addition, these flow regimes are affected by reservoir parameters and fracture properties such as half length of fracture, fracture permeability, drainage area, horizontal well length, etc. Hence, one or more flow regimes may not be present under certain conditions. 


\section{CHAPTER 2}

\section{LITERATURE REVIEW}

\subsection{Unconventional Reservoirs}

Conventional reservoirs are high permeability reservoirs. Hence, they can produce at the commercial flow rate without stimulation treatments or any special recovery process.

The unconventional reservoirs cannot be produced at an economic flow rate. The low permeability reservoirs such as shale gas, tight sand, and coal bed methane require massive stimulation treatments to improve the permeability. Hence, horizontal drilling and hydraulic fracturing are proven technologies for production from the low permeability reservoirs at an economic flow rate.

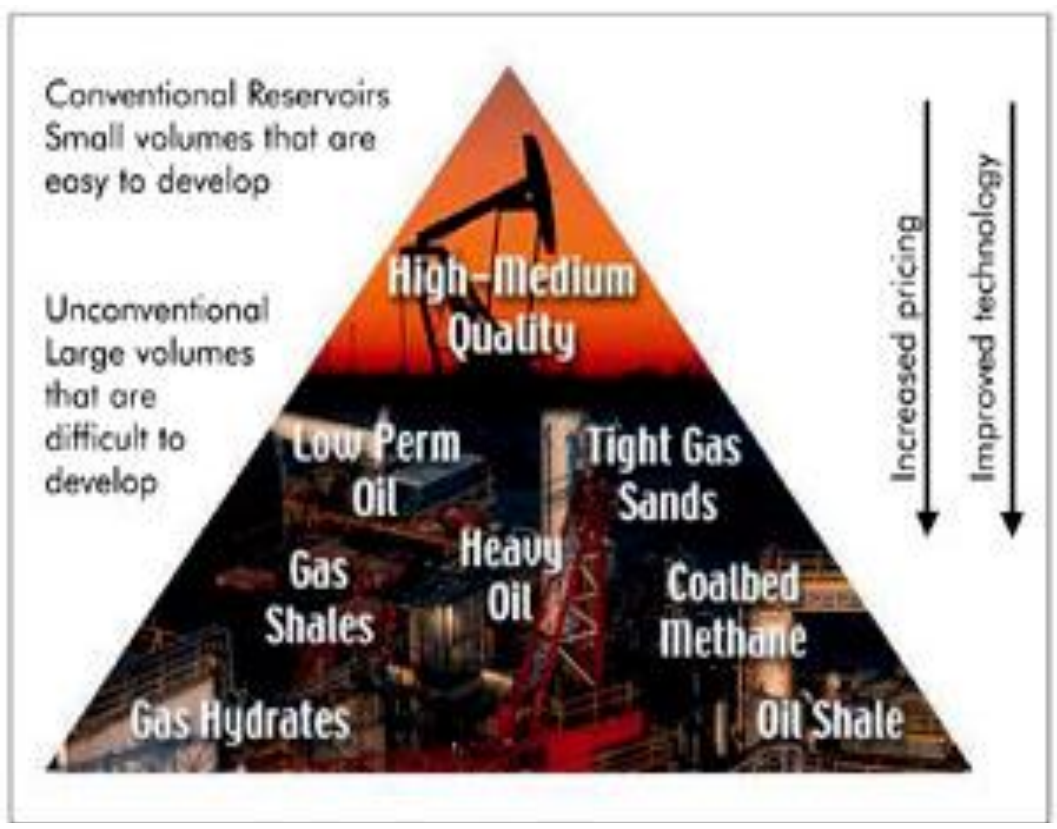

Figure 1: The Resources triangle of both conventional and unconventional resources (Naik, G.C) 
The unconventional gas reservoirs have become more attractive in recent years, while at the same time conventional gas reserves are declining. Over the last decade, production from unconventional sources in the USA has increased nearly $65 \%$, from 5.4 Tcf per year [Tcf/Y] in 1998 to 8.9 Tcf/Y in 2007, as shown in Figure 2. This means unconventional production now accounts for $46 \%$ of the total of United States production.

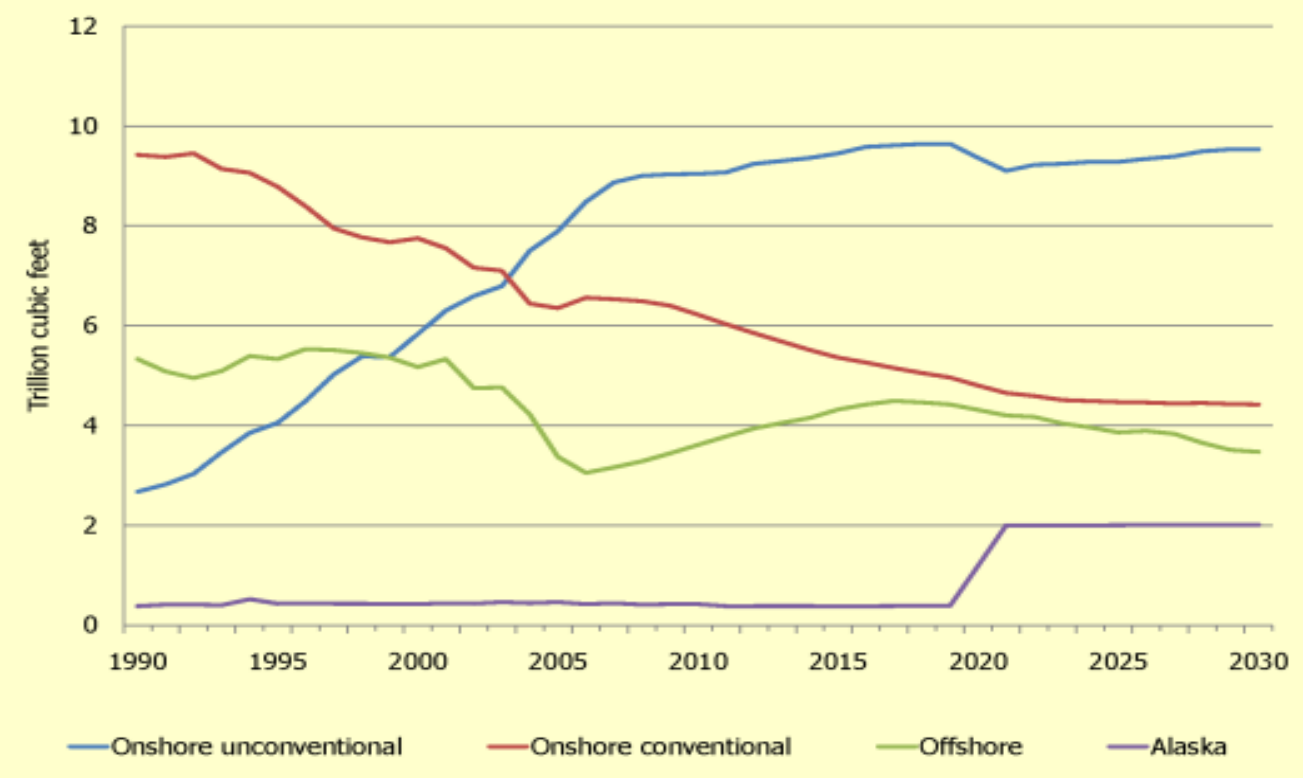

Figure 2: United States conventional and unconventional natural gas production (Zammerilli, Anthony M., 2010)

\subsection{Shale Gas}

Natural gas production from shale formations (shale gas) has grown significantly in recent years and become an important source in the United States. Gas shales are organic-rich formations that were previously regarded only as source rocks and seals for gas accumulating in conventional sandstone and carbonate reservoirs (Zammerilli, Anthony M., 2010).Wells may be drilled either vertically or horizontally and most are hydraulically fractured to stimulate production. 
The shale gas resources present in the lower 48 states are shown in Figure 3. The most active shales are the Barnett Shale, the Haynesville shale, the Antrim Shale, the Fayetteville Shale, the Marcellus Shale, and the New Albany Shale. Table 1 explains the comparison of data for gas shales in the United States.

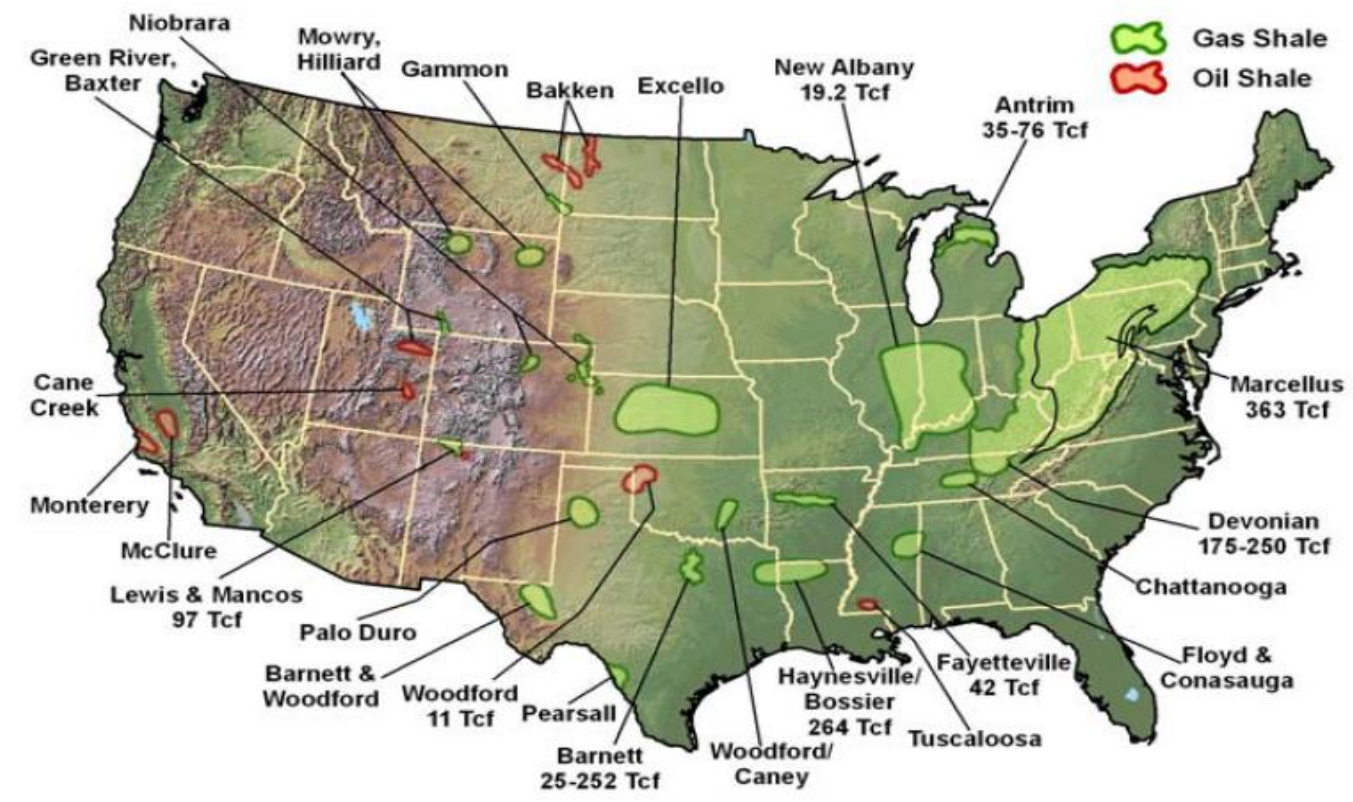

Figure 3: Gas shale basins in the United States with estimated gas reserves (after Daniel Arthur, 2009)

\subsection{Horizontal well}

In the last few years, many horizontal wells have been drilled around the world. The major purpose of a horizontal well is to enhance reservoir contact and thereby enhance well productivity. Horizontal well technology has been successfully applied in unconventional reservoirs (Low permeability reservoirs) to improve the gas production rate. Horizontal wells are now common in many reservoir management applications. Horizontal drilling with multiple hydraulic fracturing is the key to improve the productivity of the wells especially those which are drilled in tight formation reservoirs. 
According to Joshi, S.D (1991), the use of horizontal wells has been increasing very rapidly throughout the oil or gas industry as advances in drilling techniques continue. The major advantage of a horizontal well is used to increase reservoir contact area over vertical wells. Currently, one can drill as long as a 3,000 to 4,000 ft long well. Horizontal wells have been used effectively in the following applications:

1) Intersecting natural fractures as shown in Figure 4.

2) Exploiting thin oil and gas zones (Figure 4).

3) Reducing water and gas coning (Figure 4).

4) Enhancing heavy oil recovery (Figure 4).

5) In the reservoir with vertical bedding planes "multiple layers" as shown in Figure 5.

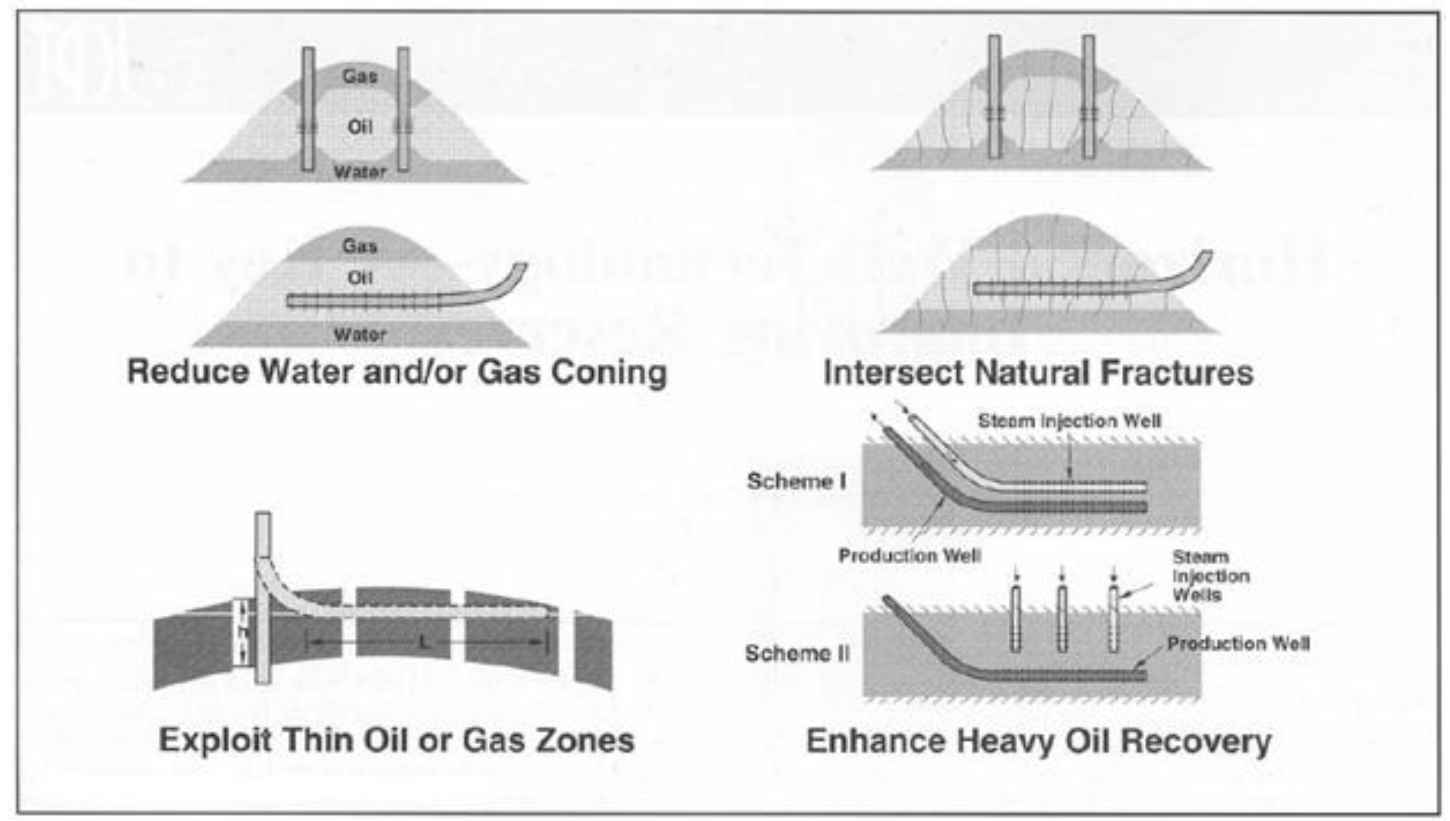

Figure 4: Applications of horizontal wells (Thakur, G.C., 1999) 
Table 1: Comparison of data for gas shales in the United States (Daniel Arthur, 2009)

\begin{tabular}{|c|c|c|c|c|c|c|c|c|}
\hline $\begin{array}{c}\text { Gas Shale } \\
\text { Basin }\end{array}$ & Barnett & Marcellus & Fayetteville & Haynesville & Woodford & Antrim & $\begin{array}{c}\text { New } \\
\text { Albany }\end{array}$ & Lewis \\
\hline $\begin{array}{l}\text { Estimated } \\
\text { Basin Area, } \\
\text { square miles }\end{array}$ & 5,000 & 95,000 & 9,000 & 9,000 & 11,000 & 12,000 & 43,500 & 10,000 \\
\hline Depth, $\mathrm{ft}$ & $\begin{array}{c}6,500- \\
8,500\end{array}$ & $\begin{array}{c}4,000- \\
8,500\end{array}$ & $\begin{array}{l}1,000- \\
7,000\end{array}$ & $\begin{array}{c}10,500- \\
13,500\end{array}$ & $\begin{array}{l}6,000- \\
11,000\end{array}$ & $\begin{array}{l}600- \\
2,200\end{array}$ & $\begin{array}{l}500- \\
2,000\end{array}$ & $\begin{array}{r}3,000- \\
6,000\end{array}$ \\
\hline $\begin{array}{l}\text { Net Thickness, } \\
\mathrm{ft}\end{array}$ & $\begin{array}{l}100- \\
600\end{array}$ & $50-200$ & $20-200$ & $200-300$ & $120-220$ & $70-12$ & $50-100$ & $200-300$ \\
\hline $\begin{array}{l}\text { Depth to Base } \\
\text { of Treatable } \\
\text { Water, } \mathrm{ft}^{*}\end{array}$ & $\sim 1200$ & $\sim 850$ & -500 & -400 & $\sim 400$ & $\sim 300$ & $\sim 400$ & $\sim 2000$ \\
\hline $\begin{array}{l}\text { Rock Column } \\
\text { Thickness } \\
\text { between Top of } \\
\text { Pay and Bottom } \\
\text { of Treatable } \\
\text { Water }\end{array}$ & $\frac{5,300-}{7,300}$ & $\begin{array}{c}2,125- \\
7650\end{array}$ & $\begin{array}{l}500- \\
6,500\end{array}$ & $\begin{array}{c}10,100- \\
13,100\end{array}$ & $\begin{array}{l}5,600- \\
10,600\end{array}$ & $\begin{array}{l}300- \\
1,900\end{array}$ & $\begin{array}{l}100- \\
1,600\end{array}$ & $\begin{array}{c}1,000- \\
6,000\end{array}$ \\
\hline $\begin{array}{l}\text { Total Organic } \\
\text { Carbon, } \%\end{array}$ & 4.5 & $3-12$ & $4.0-9.8$ & $0.5-4.0$ & $1-14$ & $1-20$ & $1-25$ & $0.45-2.5$ \\
\hline $\begin{array}{l}\text { Total Porosity. } \\
\%\end{array}$ & $4-5$ & 10 & $2-8$ & $8-9$ & $3-9$ & 9 & $10-14$ & $3.0-5.5$ \\
\hline $\begin{array}{l}\text { Gas Content, } \\
\text { scfiton }\end{array}$ & $\begin{array}{l}300- \\
350\end{array}$ & $60-100$ & $60-220$ & $100-330$ & $200-300$ & $40-100$ & $40-80$ & $15-45$ \\
\hline $\begin{array}{l}\text { Water } \\
\text { Production, } \\
\text { Barrels } \\
\text { water/day }\end{array}$ & 0 & 0 & 0 & 0 & & $5-500$ & $5-500$ & 0 \\
\hline $\begin{array}{l}\text { Well spacing. } \\
\text { Acres }\end{array}$ & $60-160$ & $40-160$ & $80-160$ & $40-560$ & 640 & $40-160$ & 80 & $80-320$ \\
\hline $\begin{array}{l}\text { Original Gas-In- } \\
\text { Place, Tcf }\end{array}$ & 327 & 1,500 & 52 & 717 & 52 & 76 & 160 & 61.4 \\
\hline Reserves, Tof & 44 & 262,500 & 41.6 & 251 & 11.4 & 20 & 19.2 & 20 \\
\hline $\begin{array}{l}\text { Est. Gas } \\
\text { Production, } \\
\text { mcfiday/well }\end{array}$ & 338 & 3,100 & 530 & $625-1,800$ & 415 & $\begin{array}{l}125- \\
200\end{array}$ & & $100-200$ \\
\hline \multicolumn{9}{|c|}{ mcf = thousands of cubic feet of gas. } \\
\hline \multicolumn{9}{|c|}{$\begin{array}{l}\text { NOTE: Data derived from various sources and research analysis. Information from some basins was unable to be } \\
\text { identified and confirmed at the time of this paper and has been left blank. }\end{array}$} \\
\hline \multicolumn{9}{|c|}{$\begin{array}{l}\text { SOURCE: Hayden \& Pursell, 2005; Halliburton, 2008; Navigant Consulting, 2008; Drilling Contractor, 2000; Boughal, } \\
\text { 2008; Berman, 2008; Haines, 2006; Arkansas Oil and Gas Commiscion, 2008; Nyahay, Leone, Smith, Martin, \& Jarvie, } \\
\text { 2007; Cardott, 2004; Soeder, 1986; Vulgamore et al, 2007; Petroleum Listing Services, 2008; Jochen, 2006; Sumi, } \\
\text { 2008; Engelder \& Lash, 2008; Willams, 2008; Gas Leases, 2008; US Energy Investor, 2005. }\end{array}$} \\
\hline
\end{tabular}




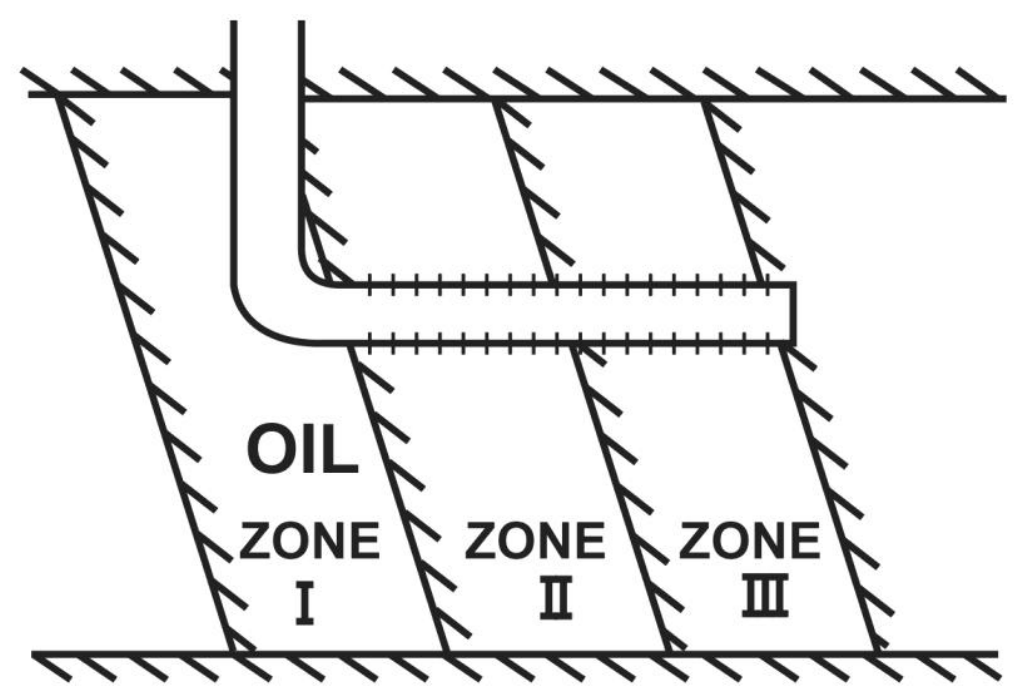

Figure 5: A horizontal well with vertical bedding planes (Joshi, S.D, 1991)

The major disadvantage is that one pay zone can be drained per horizontal well. The other disadvantage of horizontal wells is the higher cost. Typically it costs about 1.4 to 3 times more than a vertical well. Hence, for an economic success, producible reserves from a horizontal well not only have to be proportionately larger, but they should also be produced in a shorter span than a vertical well (Joshi, S.D, 1991).

\subsection{Hydraulic Fracturing of Horizontal Well}

The main objective of the fractured a horizontal well is to improve the production capability of the well to achieve commercial flow rates as well as to prevent the damage around the wellbore. Hydraulic fracturing is a formation stimulation practice used to create additional permeability in a producing formation. By creating additional permeability, hydraulic fracturing 
facilitates the migration of fluids to the wellbore for purposes of production (Daniel Arthur, 2009).

Hydraulic fracturing involves pumping of a fluid into a formation at a calculated, predetermined rate and pressure to generate fractures or cracks in the target formation. For shale gas development, fracture fluids are primarily water-based fluids mixed with additives which help the water to carry sand propant in the fractures. The sand propant is needed to "prop" open the fractures once the pumping of the fluids is stopped. Once the fracture has initiated, additional fluids are pumped into the wellbore to continue the development of the fracture and to carry the propant deeper into the formation. Additional fluids are needed to maintain the downhole pressure necessary to accommodate the increasing length of the opened fracture in the formation. (Ground Water Protection Council, 2009).

\subsection{Dimensionless Fracture Conductivity}

The dimensionless fracture conductivity $\left(\mathbf{F}_{\mathbf{c d}}\right)$ is one of the important parameters in a well stimulation design. The dimensionless fracture conductivity plays an important role to determine the kind of flow regimes. By the below equation, if the $F_{c d}$ is less than 100, it shows bilinear flow which occurs in finite "low" fracture conductivity, or if the $\mathrm{F}_{\mathrm{cd}}$ is more than 100 , it shows linear flow which occurs in infinite "high" fracture conductivity. The $\mathbf{F}_{\mathbf{c d}}$ is a function of the fracture permeability $\left(\mathrm{k}_{\mathrm{f}}\right)$, fracture width $\left(\mathrm{w}_{\mathrm{f}}\right)$, formation permeability $(\mathrm{k})$, and fracture half length $\left(\mathrm{x}_{\mathrm{f}}\right)$.

$$
F_{c d}=\frac{k_{f} w_{f}}{k x_{f}}
$$

The conductivity fracture can be divided into: 


\subsubsection{Infinite Conductivity Fracture}

There is no pressure drop along the fracture

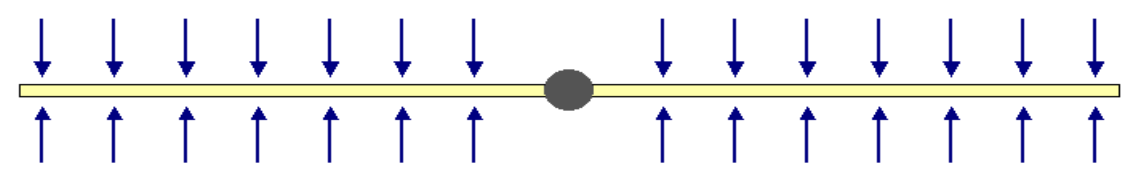

Figure 6: Infinite conductivity fracture (Schlumberger, 1998)

\subsubsection{Finite Conductivity Fracture}

In this case, there is pressure drop along fracture

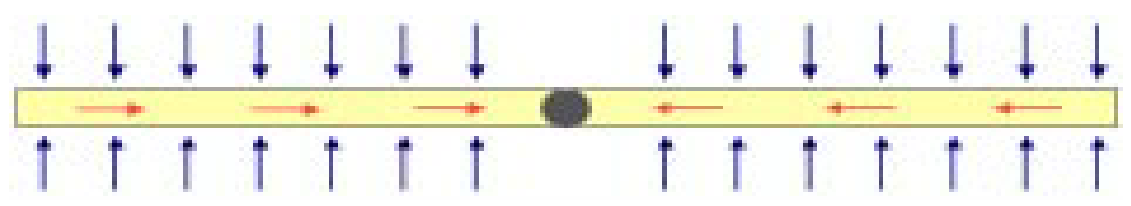

Figure 7: Finite conductivity fracture (Schlumberger, 1998)

In addition to that, bilinear flow occurs in finite "low" fracture conductivity, and linear flow occurs in infinite "high" fracture conductivity, on log-log plot of pressure change and derivative pressure versus time. The log-log plot exhibits slope of one-quarter for bilinear flow and slope of one-half for linear flow. 


\subsection{Pressures Transient Analysis}

Well test analysis for both vertical and horizontal wells is a powerful tool for determining the complex reservoir characteristics. Well testing is used to estimate the absolute permeability $(\mathrm{k})$, skin factor $(\mathrm{s})$, reservoir pressure $\left(\mathrm{p}_{\mathrm{r}}\right)$, fracture half-length $\left(\mathrm{x}_{\mathrm{f}}\right)$, and fracture conductivity $\left(\mathrm{k}_{\mathrm{f}}\right.$ $\left.\mathrm{w}_{\mathrm{f}}\right)$.

There are different flow regimes that may occur in a horizontal well with single or multiple hydraulic fractures, including fracture radial flow, radial linear or bilinear flow, formation linear flow and pseudo-radial flow as shown in Figure 8. The flow regimes can be identified by plotting the pressure change $(\Delta \mathrm{p})$, and its derivative $\left(\Delta \mathrm{p}^{\prime}\right)$ on log-log scale versus time $(\Delta \mathrm{t})$. These flow regimes are characterized by the slope of the line on the log-log plot. Depending on the magnitudes of the reservoir parameters, one or more flow regimes may not be present.

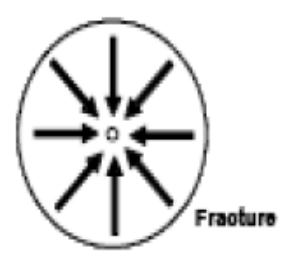

1. Fracture Radlal Flow

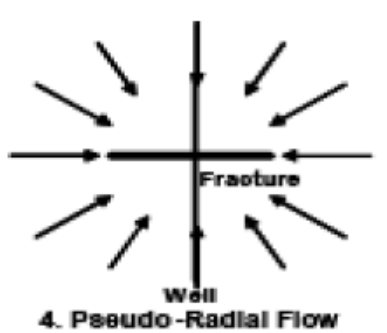

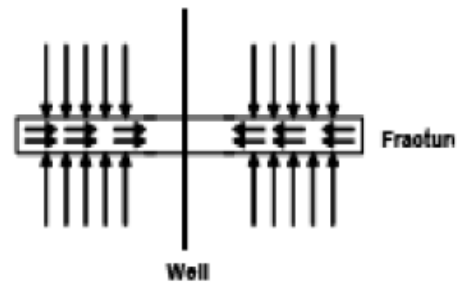

2. Radlal-linear or Billnear Flow

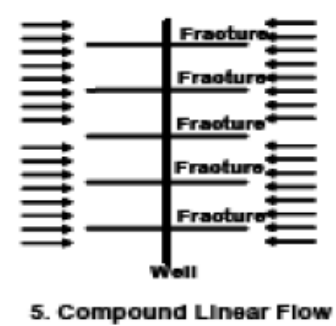

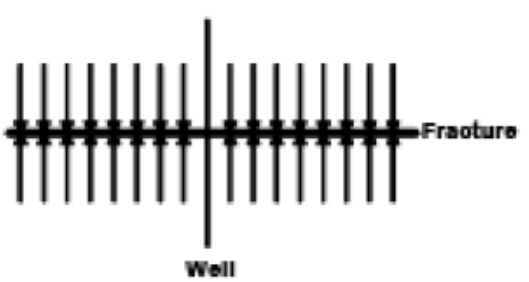

3. Formation LInear Flow

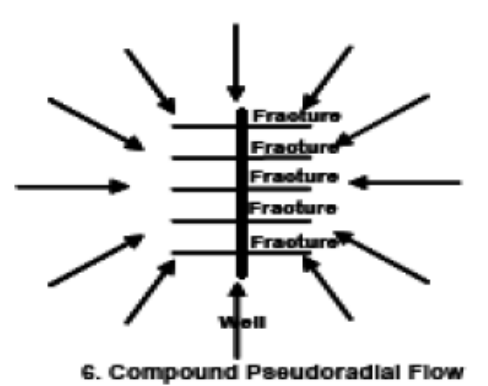

Figure 8: Flow regimes for fractured horizontal wells (Ozkan, E et al, 2006) 


\subsection{Flow Regimes for Fractured Horizontal Well}

There are different flow regimes that may be present in horizontal well with single or multiple hydraulic fractures.

1. Fracture Radial Flow

2. Radial-Linear Flow

3. Formation Linear Flow

4. Bilinear Flow

5. Pseudo-Radial Flow

6. Compound Linea Flow (Trilinear Flow)

7. Compound Pseudoradial Flow

\subsubsection{Fracture Radial Flow}

Larsen and Hegre (1994) found that, during this flow period, the production only is coming from the fracture. The fracture radial flow usually is masked by wellbore storage. It is characterized by a zero slope on the log-log graph. The duration of the fracture radial flow is usually very short.

\subsubsection{Radial-Linear Flow}

The radial-linear flow is usually encountered very early in time and it will most likely be masked by the presence of wellbore storage. The flow period is called radial-linear flow because the flow is radial towards the wellbore in the fracture and linear towards the fracture surface in the formation. 


\subsubsection{Bilinear Flow}

The bilinear flow is present whenever most of the fluid entering the wellbore comes from the formation and fracture tip effects have not yet affected the well behavior. The bilinear flow is exhibited by finite conductivity fractures, $\left(\mathrm{C}_{\mathrm{fd}}<100\right)$. This flow regime has two linear flows occurring simultaneously, one of the linear flows is in the fracture and the other linear flow is in the formation. During the bilinear flow period, $(\Delta \mathrm{p})$ is the linear function of $\left(\mathrm{t}^{1 / 4}\right)$ on Cartesian coordinate paper. A log-log plot of $(\Delta \mathrm{p})$ as a function of time exhibits a slope of one-quarter; the derivative also has a slope of one-quarter during this time period (Lee, J. and Wattenbarger, R. A., 1996).

\subsubsection{Formation Linear Flow}

The formation linear flow occurs when horizontal linear flow in the formation is towards the fracture and incompressible flow behavior in the fracture. The formation linear flow is exhibited by high conductivity fracture $\left(\mathrm{C}_{\mathrm{fd}}>100\right)$. On Cartesian coordinate paper, $(\Delta \mathrm{p})$ is a linear function of $\left(\mathrm{t}^{1 / 2}\right)$, and $\log$-log plots of both $(\Delta \mathrm{p})$ and pressure derivative as a function of time exhibits a slope of one-half (Lee, J. and Wattenbarger, R. A.,(1996) and Larsen and Hegre, (1994)).

\subsubsection{Pseudo-Radial Flow}

Pseudo-radial flow is very similar to the radial flow which commonly occurs in the reservoir. It usually takes a significant amount of time to be present. Pseudo-radial flow occurs as soon the reservoir has stabilised and behaves like a common reservoir. It is characterized by a zero slope on the log-log graph. 


\subsubsection{Compound Linear Flow (Trilinear Flow)}

Brown et al (2009) explained the concept of the trilinear flow for fractured horizontal wells. They indicated that the basis of the trilinear flow is the productive life for hydraulically fractured wells dominated by linear flow regimes, as shown in Figure 9. The trilinear flow couples three linear flow regions, including the outer reservoir beyond the tips of the hydraulic fractures, inner reservoir between the hydraulic fractures, and the hydraulic fracture.

\subsubsection{Compound Pseudoradial Flow}

The Compound Pesudoradial flow couples radial flows in two contiguous flow regions, the outer reservoir beyond the tips of the hydraulic fractures and the inner reservoir between hydraulic fractures. Due to the nature of horizontal wells, it might be very difficult to economically produce till the production flow reaches a compound pseudoradial flow

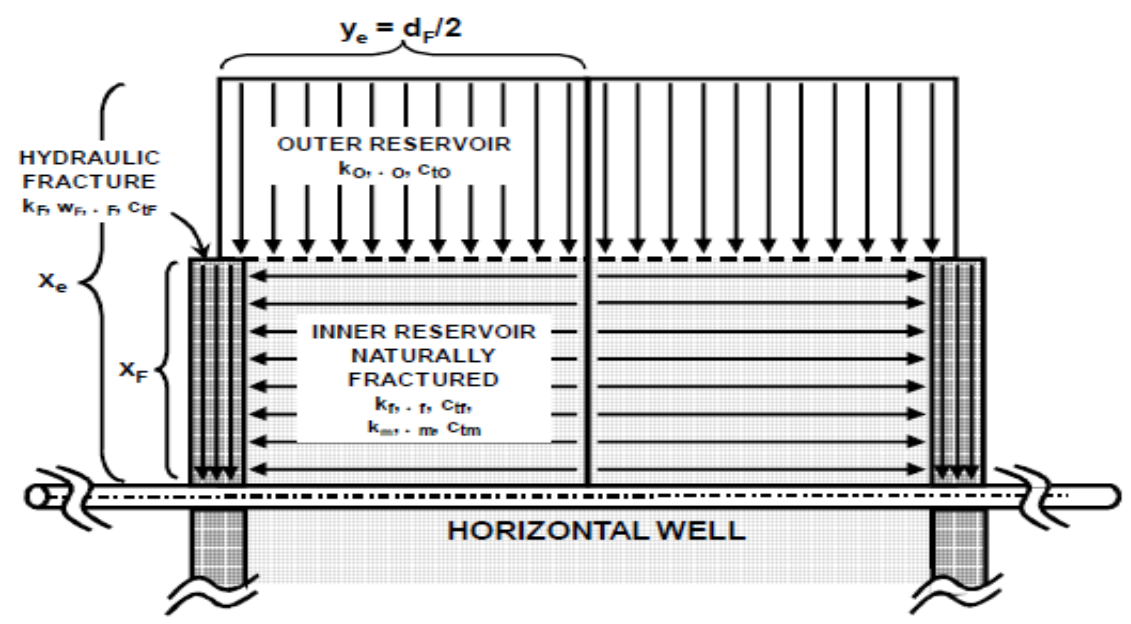

Figure 9: Trilinear flow regimes for multiple fractured horizontal well (Brown, M. and Ozkan, E., 2009) 


\section{CHAPTER 3}

\section{OBJECTIVE AND METHODOLOGY}

The objective of this research is to analyze the impact of the reservoir and the fracture properties of horizontal well on flow regimes. The following methodology was employed to achieve the objectives:

- A numerical reservoir model was developed to predict the pressure as a function of time.

- The impact of the number of hydraulic fractures on flow regimes was investigated.

- The impact of the fracture properties on flow regimes was investigated.

- The impact of reservoir properties on the flow regimes was investigated.

\subsection{Numerical Models}

The Eclipse was used in this study to develop the numerical reservoir model. The model was developed with a horizontal well and multiple hydraulic fractures in a very low permeability reservoir. In addition, the model consisted from five layers. The reservoir model is produced at a constant rate for one year. Table 2 shows the parameters and values in the base model and Table 3 shows the ranges of value used in the model. Figures 10 and 11 illustrate the two base models used in this study.

\subsection{Base Model Parameters and Assumptions}

In order to understand the impact of different reservoir and fracture parameters on the flow regimes, a series of cases (numerical reservoir models) were derived from the base case by changing a particular parameter while keeping the other parameters unchanged and were run using a commercial reservoir simulator. The following items are the reservoir and fracture parameters which impacts were studied: 


\section{i. Number of hydraulic fractures}

The investigation assumes that the horizontal well was hydraulically fractured at the center of the well length $(\mathrm{L} / 2)$ with one fracture. The base model parameters used are; drainage area $=$ $4000 \times 2000 \mathrm{ft}^{2}$, horizontal well length $=3000 \mathrm{ft}$, reservoir permeability $(\mathrm{kx}=\mathrm{ky})=0.001 \mathrm{md}$ and $(\mathrm{Kz})=0.0001 \mathrm{md}$, fracture half length $(\mathrm{Xf})=500 \mathrm{ft}$, the fracture width $\left(\mathrm{w}_{\mathrm{f}}\right)=0.1 \mathrm{inch}$, fracture permeability $\left(\mathrm{k}_{\mathrm{f}}\right)=10,000 \mathrm{md}$ and the fracture porosity is $10 \%$. Also, more than one fracture were added to the model to see how the results may change based on the number of the fractures in the horizontal well.

\section{ii. Reservoir permeability}

To study the impact of the permeability on flow regimes, few more cases were run with lower permeability values in $\mathrm{x}, \mathrm{y}, \mathrm{z}$ directions. The reservoir permeability were $0.0001 \mathrm{md}$ in $\mathrm{x}$ and y directions and $0.00001 \mathrm{md}$ in $\mathrm{z}$ directions. Also, this case used for different numbers of hydraulic fractures.

\section{iii. Fracture width}

In order to investigate the impact of the fracture width on flow regimes, the lower fracture width was used, $w_{f}=0.01$ inch. This case was run in different values of reservoir permeability, $\mathrm{kx}=0.001 \mathrm{md}$ and $0.0001 \mathrm{md}$.

\section{iv. Drainage area and horizontal well length}

The drainage area and the horizontal well length configuration are considered in this section, the drainage area was to $4000 \mathrm{ft}$ in length and $1000 \mathrm{ft}$ in width with the horizontal well 
length of $4000 \mathrm{ft}$ as shown in Figure 11. This case was run with different values of the reservoir permeability. $\mathrm{kx}=0.001 \mathrm{md}$ and $0.0001 \mathrm{md}$.

\section{v. Fracture permeability}

Two different values of fracture permeability were used in this study. 10,000 md and 40,000 md.

\section{vi. Fracture half length}

To examine the impact of the fracture half length on flow regimes, two values of fracture half length were used $-300 \mathrm{ft}$ and $500 \mathrm{ft}$.

\section{vii. $\quad$ Fracture porosity}

The fracture porosity was varied from $5 \%$ to $50 \%$.

Every derived case was run for the number of hydraulic fractures of 1, 2, 3, 4, 7, and 13 except the cases where fracture permeability, fracture half length, and fracture porosity were studied. Pressure derivative vs. time plot was used for all above cases. In addition, these cases were run at base model parameters that are mentioned in Table 2.

\subsection{Data Analysis}

Five-point method was used to estimate the derivative pressure as shown in Figure 12. The following procedure used to identify the flow regimes in this study:

- Plot pressure derivative versus time on log-log plot (Diagnostic Plot). The slopes of the pressure derivative curve are mainly used to identify flow regimes.

- Identify fracture radial flow when zero slope straight line appears

- Identify bilinear flow when a quarter-slope straight line appears.

- Identify the formation linear flow when a half-slope straight line appears 
- Identify the start of transitional flow at the end of first formation linear flow and the beginning of second formation linear flow.

Table 2: Parameters and values used in the base model

\begin{tabular}{|c|c|}
\hline \multicolumn{2}{|l|}{ Reservoir Parameters } \\
\hline Period of production (years) & 1 year \\
\hline Grid size $(\mathrm{ft})$ & $100 \times 100$ \\
\hline Model Geometry & Multilayer Reservoir (5 layers) \\
\hline Shape & Rectangular \\
\hline Depth, ft & 7,000 \\
\hline Reservoir length, $\mathrm{ft}$ & 4,000 \\
\hline Reservoir width, ft & 2,000 \\
\hline Horizontal well length, $\mathrm{ft}$ & 3,000 \\
\hline Thickness, $\mathrm{ft}$ & 100 \\
\hline \multicolumn{2}{|l|}{ Rock Properties } \\
\hline Porosity Type & Single \\
\hline Reservoir porosity, fraction & 0.05 \\
\hline X-direction Permeability (md) & 0.001 \\
\hline Y-direction Permeability (md) & 0.001 \\
\hline Z-direction Permeability (md) & 0.0001 \\
\hline Compressibility, 1/ psia & $1 \times 10^{-6}$ \\
\hline Density, $\mathrm{lb} / \mathrm{ft}^{3}$ & 150 \\
\hline \multicolumn{2}{|l|}{ Initial Conditions } \\
\hline Reservoir pressure, psia & 3,000 \\
\hline Water saturation, fraction & 0.15 \\
\hline \multicolumn{2}{|l|}{ Hydraulic Fracture Properties } \\
\hline Half length, $\mathrm{ft}$ & 500 \\
\hline Width, inch & 0.1 \\
\hline Top of fracture, $\mathrm{ft}$ & 7,000 \\
\hline Bottom of fracture, $\mathrm{ft}$ & 7,100 \\
\hline Permeability, md & 10,000 \\
\hline Porosity, fraction & 0.1 \\
\hline \multicolumn{2}{|l|}{ Well Production Controls } \\
\hline $\mathrm{P}_{\mathrm{wf}}, \mathrm{psia}$ & 300 \\
\hline Gas flow rate, Mscfd & 100 \\
\hline \multicolumn{2}{|l|}{ Fluid Properties } \\
\hline Standard pressure, psia & 14.7 \\
\hline Standard temperature, ${ }^{\circ} \mathrm{F}$ & 60 \\
\hline Reference Temperature, ${ }^{\circ} \mathrm{F}$ & 120 \\
\hline
\end{tabular}


Table 3: Ranges of values used in the model

\begin{tabular}{|l|c|c|}
\hline Parameters & Ranges & Used Values \\
\hline Reservoir width, ft & $1,000-2,000$ & $1,000 \& 2,000$ \\
\hline Horizontal well length, ft & $3,000-4,000$ & $3,000 \& 4,000$ \\
\hline Horizontal permeability, md & $0.001-0.0001$ & $0.001 \& 0.0001$ \\
\hline Fracture half length, ft & $300-500$ & $300 \& 500$ \\
\hline Fracture Width, inch & $0.01-0.1$ & $0.01 \& 0.1$ \\
\hline Fracture Permeability, md & $10,000-40,000$ & $10,000 \& 40,000$ \\
\hline Fracture Porosity, fraction & $0.05-0.5$ & $0.05,0.1 \& 0.5$ \\
\hline Fracture Number & $1-13$ & $1,2,3,4,7 \& 13$ \\
\hline
\end{tabular}

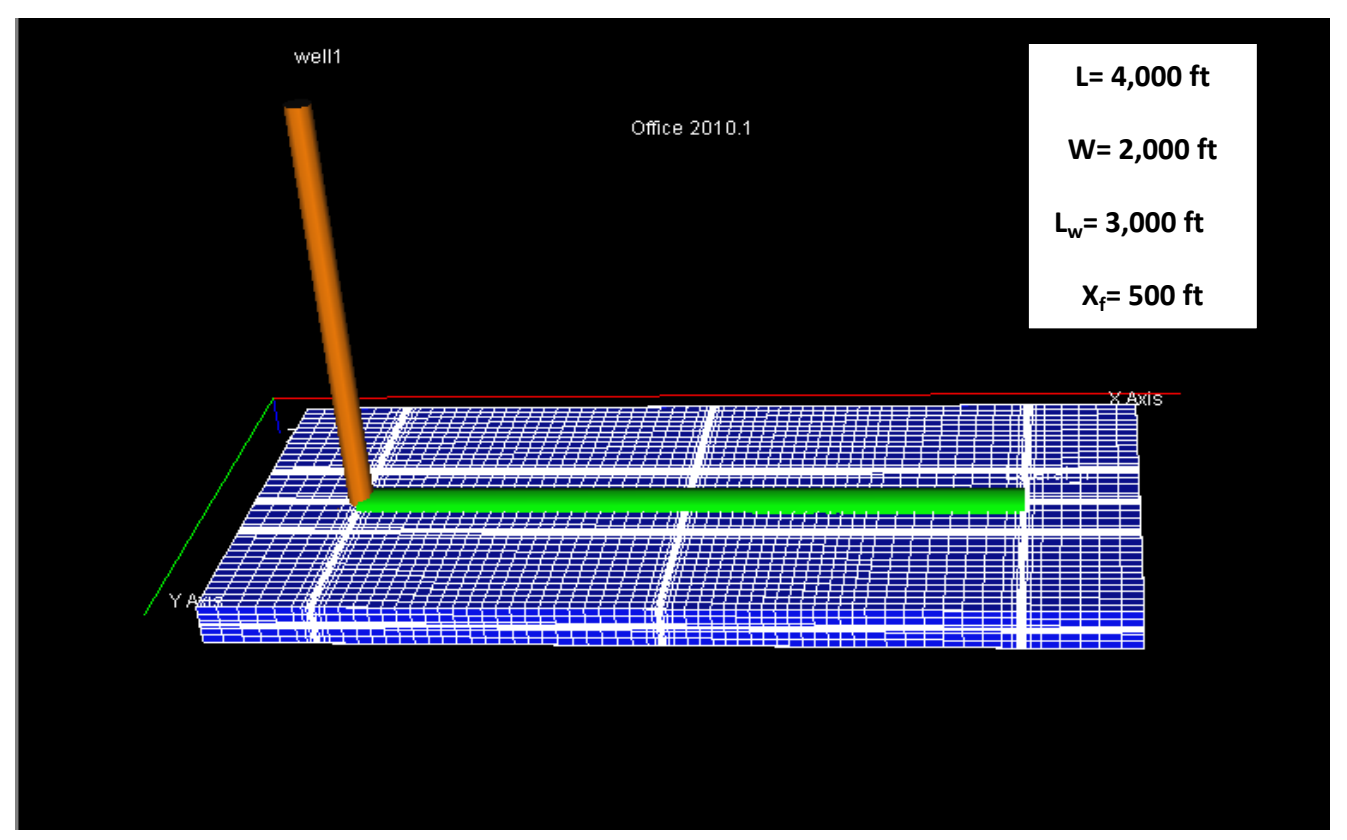

Figure 10: A horizontal well model with a 4,000 ft by $2,000 \mathrm{ft}$ and well length of $3,000 \mathrm{ft}$ 


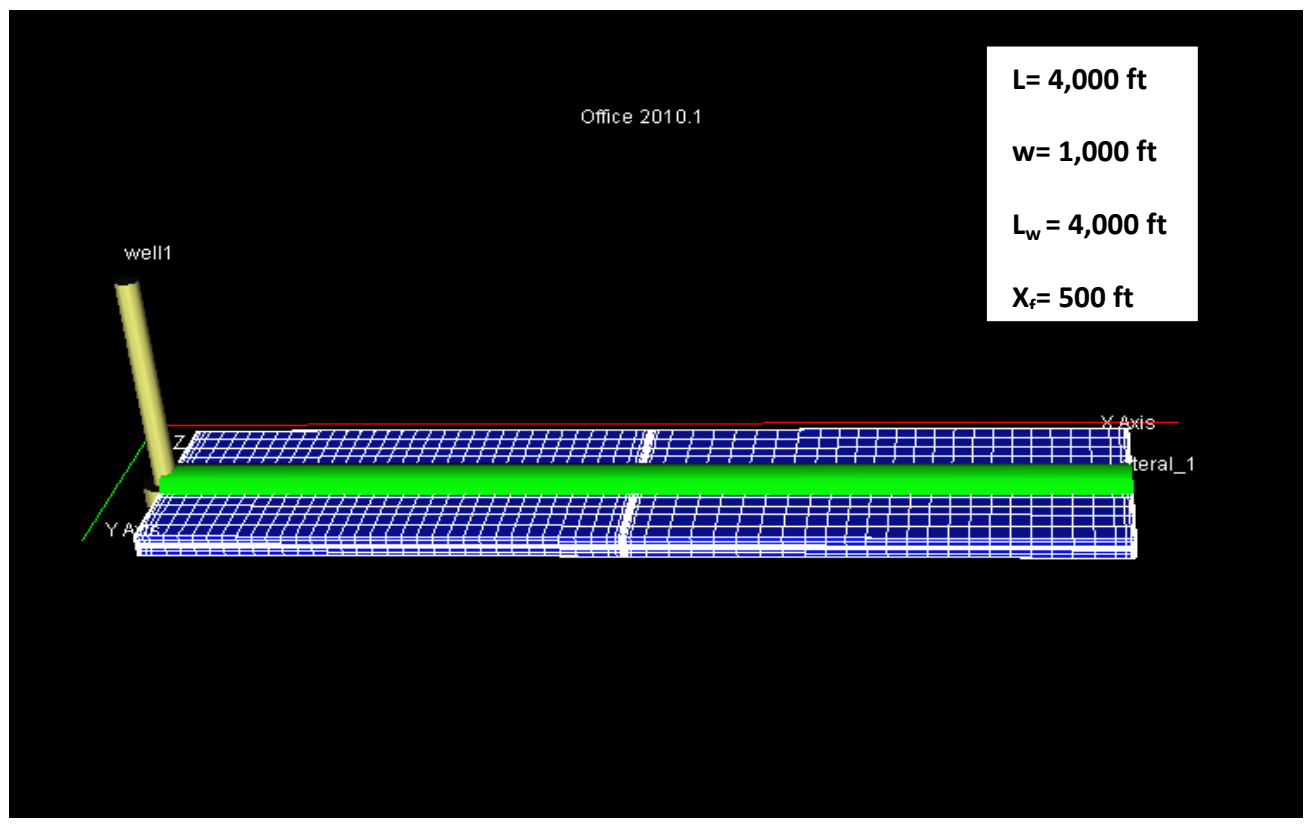

Figure 11: A horizontal well model with $4,000 \mathrm{ft}$ by $1000 \mathrm{ft}$ and well length of $4,000 \mathrm{ft}$

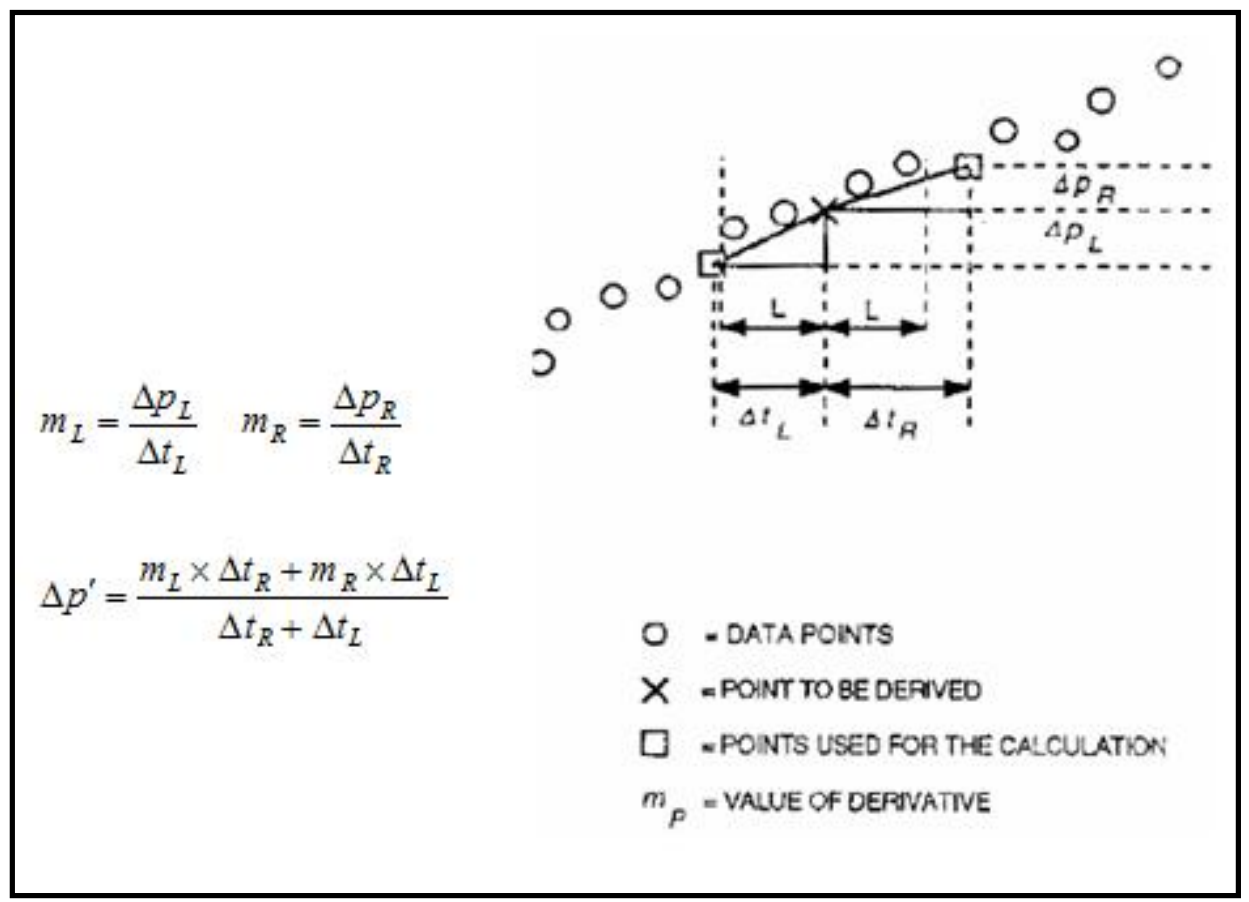

Figure 12: Five-point method for calculating the pressure derivative (Aminian, K., 2010) 


\section{CHAPTER 4 \\ RESULTS AND DISCUSSIONS}

\subsection{The Impact of the Number of Hydraulic Fractures on Flow Regimes}

Figure 13 and Figure 14 show the impact of the number of hydraulic fractures on flow regime. Figure 13 is showing the plots for 1, 2, and 3 hydraulic fractures whereas Figure 14 is showing the plots for 4, 7 and 13 hydraulic fractures. All these plots are showing the presence of bi-linear flow ( $1 / 4$ slope) as well as two separate linear flow periods ( $1 / 2$ slopes). The first linear flow is from the region between the fractures while the second one is from beyond the tip of the fracture and could be consider the compound linear flow (Trilinear flow). As the number of hydraulic fractures increases, the duration of bilinear flow as well as that of transitional flow decreases. Also the duration of transitional flow disappears at the higher number of hydraulic fractures and two separate linear flow periods coincide with each other and appear as one linear flow.

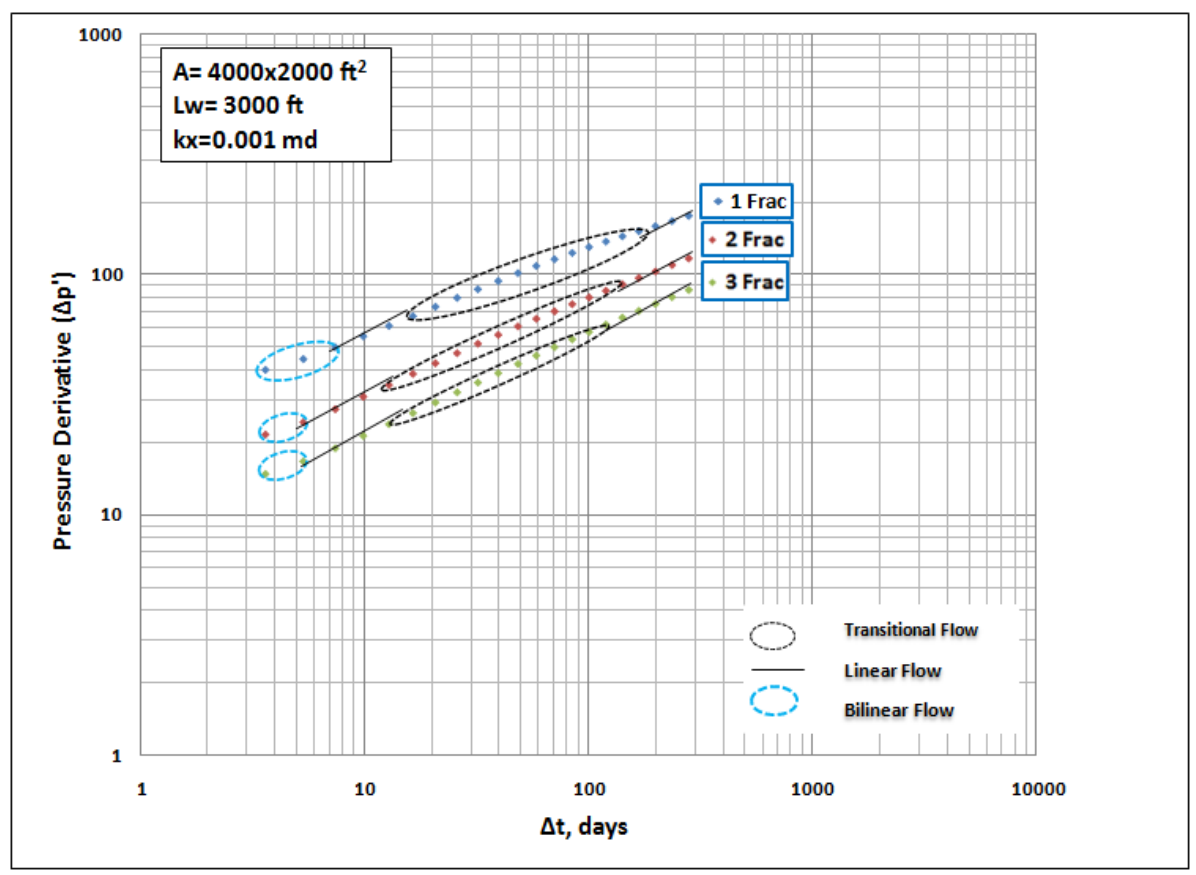

Figure 13: The impact of the number of hydraulic fractures $\left(w_{\mathrm{f}}=0.1\right.$ inch $)$ 


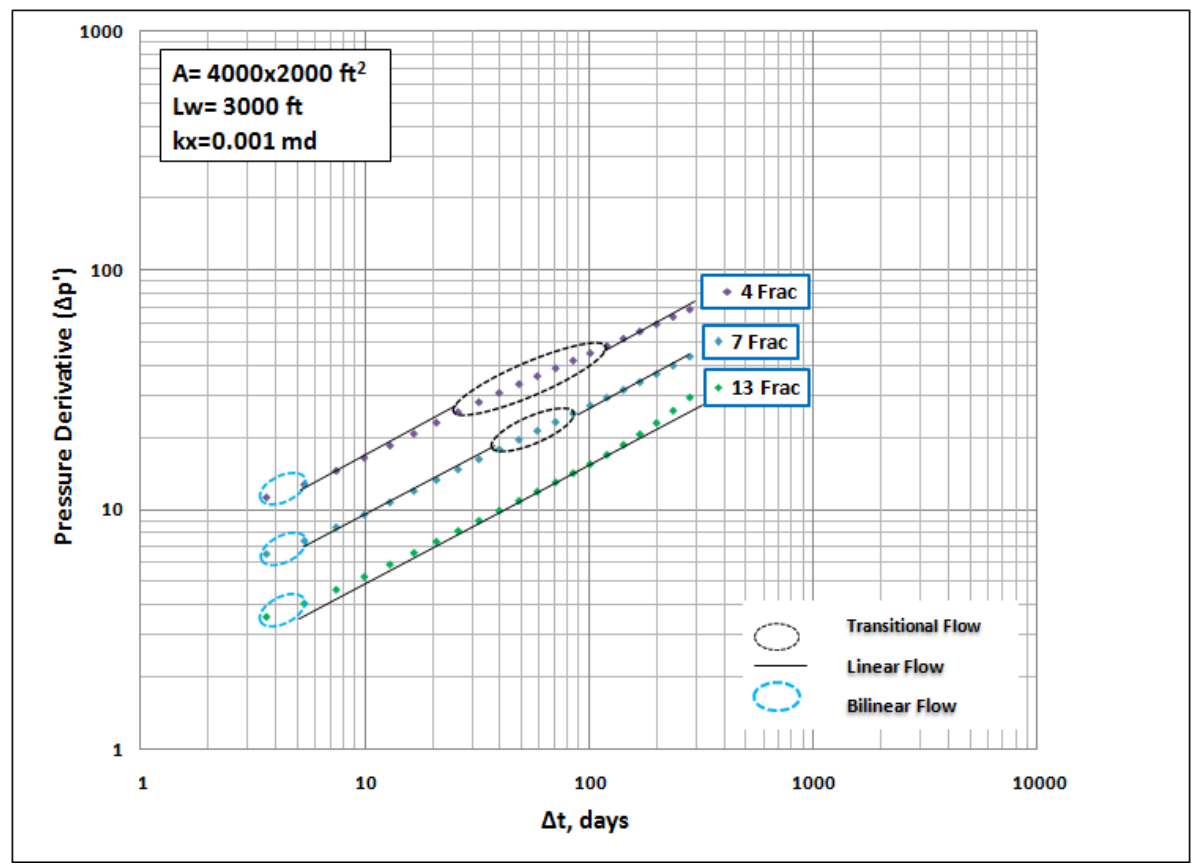

Figure 14: The impact of the number of hydraulic fractures $\left(w_{f}=0.1\right.$ inch $)$

\subsection{The Impact of Reservoir Permeability on Flow Regimes}

Figure 15 and Figure 16 show the impact of reservoir permeability on flow regimes. For these cases, the reservoir permeability values were $0.0001 \mathrm{md}$ in $\mathrm{x}$ and $\mathrm{y}$ directions and 0.00001 $\mathrm{md}$ in $\mathrm{z}$ direction. It is observed that the bi-linear flow does not appear in these cases as it did in the cases of Figure 13 and Figure 14. Thus, the decrease in the permeabilities diminishes the bilinear flow regimes. 


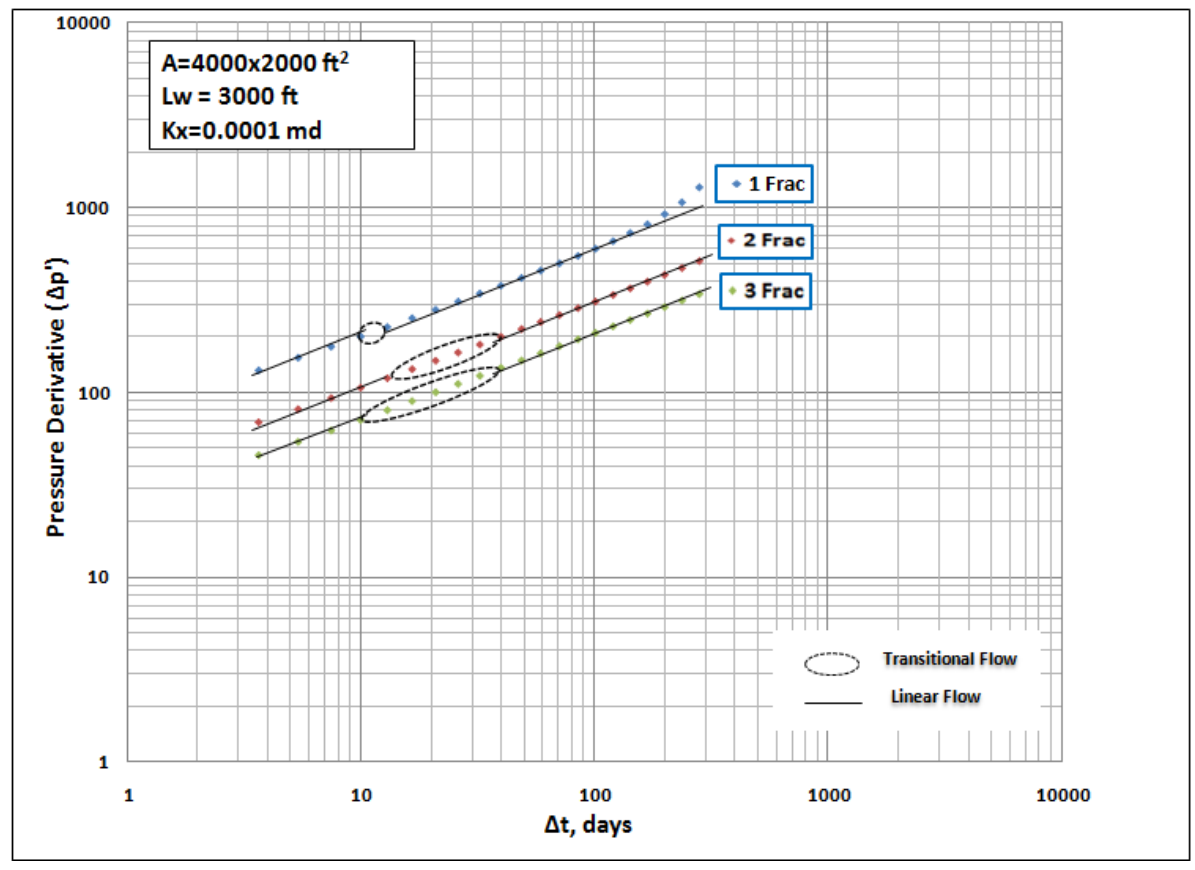

Figure 15: The impact of reservoir permeability $\left(w_{f}=0.1\right.$ inch $)$

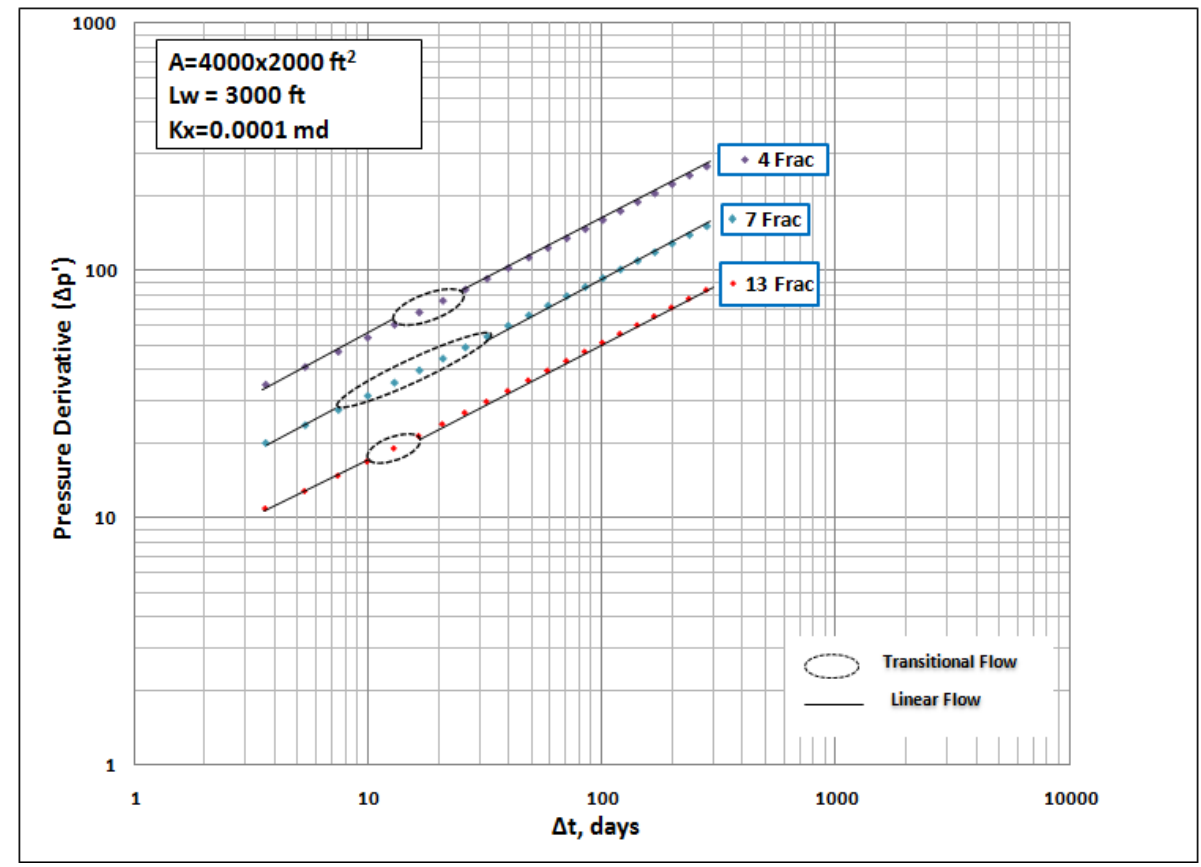

Figure 16: The impact of reservoir permeability $\left(w_{f}=0.1\right.$ inch $)$ 


\subsection{The Impact of Fracture Width on Flow Regimes}

The cases similar to Figure 13 through Figure 16 were run with a reduced fracture width of 0.01 inch and the results are plotted in Figure 17 through Figure 20. The fracture radial flow is observed for higher permeability cases as shown in Figure 17 and Figure 18. For the other two cases, Figure 19 and Figure 20, with lower reservoir permeabilities, no fracture radial flow is observed, but the bi-linear flow is present and it was followed by one linear flow.

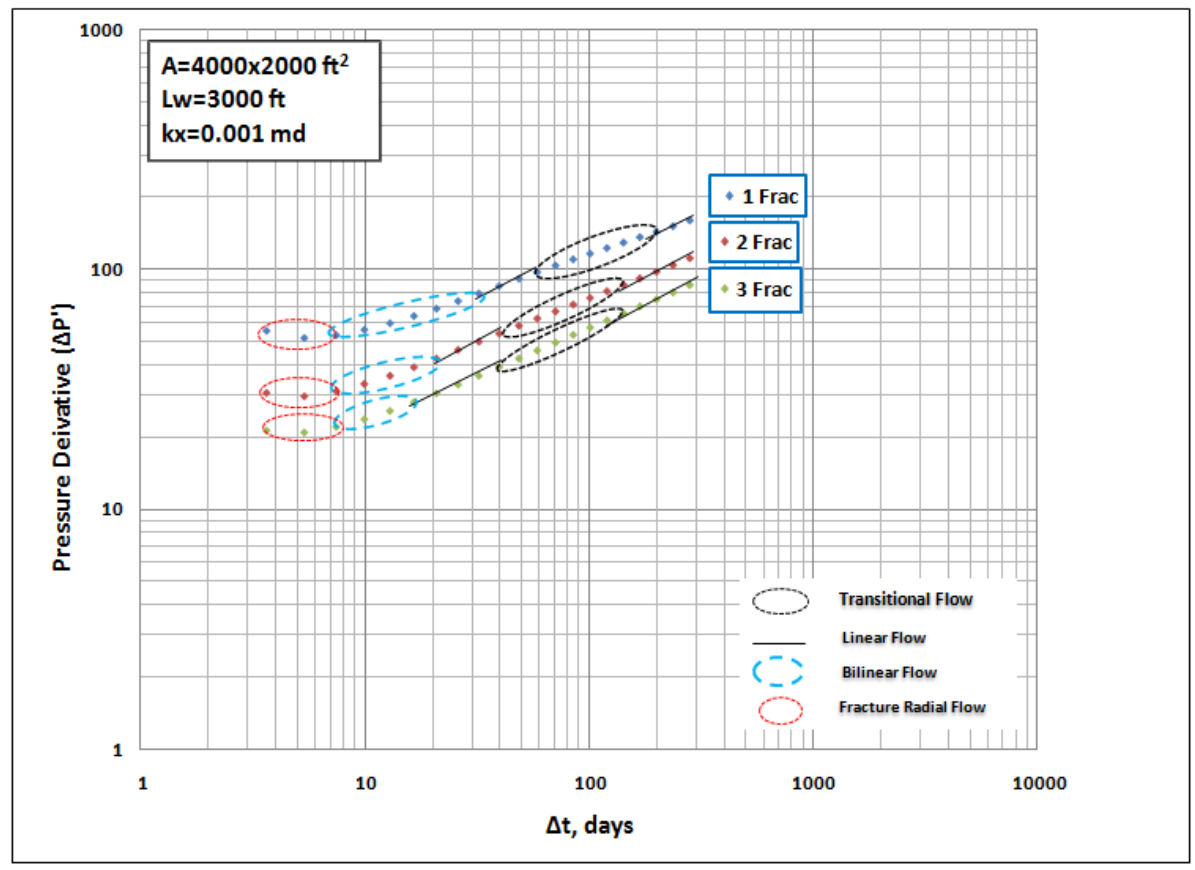

Figure 17: The impact of fracture width $\left(w_{f}=0.01\right.$ inch $)$ 


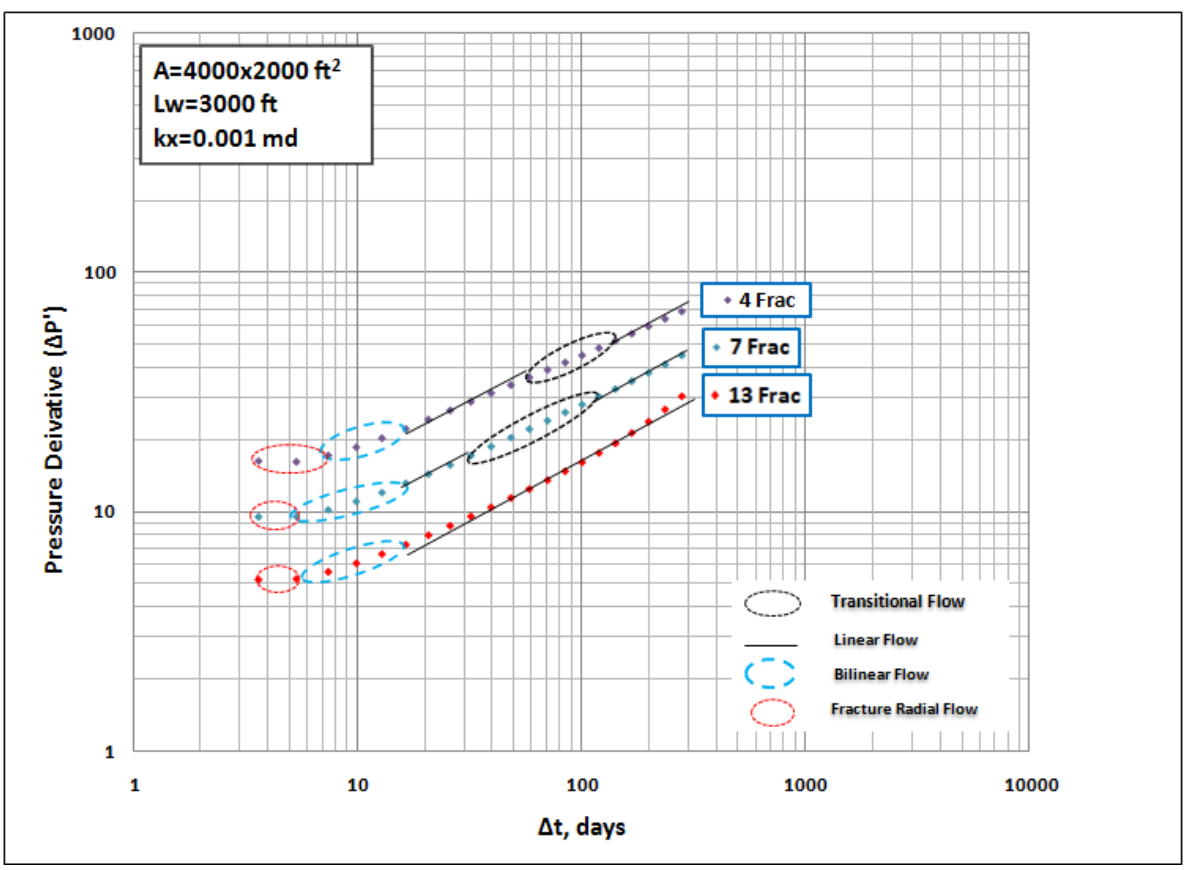

Figure 18: The impact of fracture width $\left(w_{f}=0.01\right.$ inch $)$

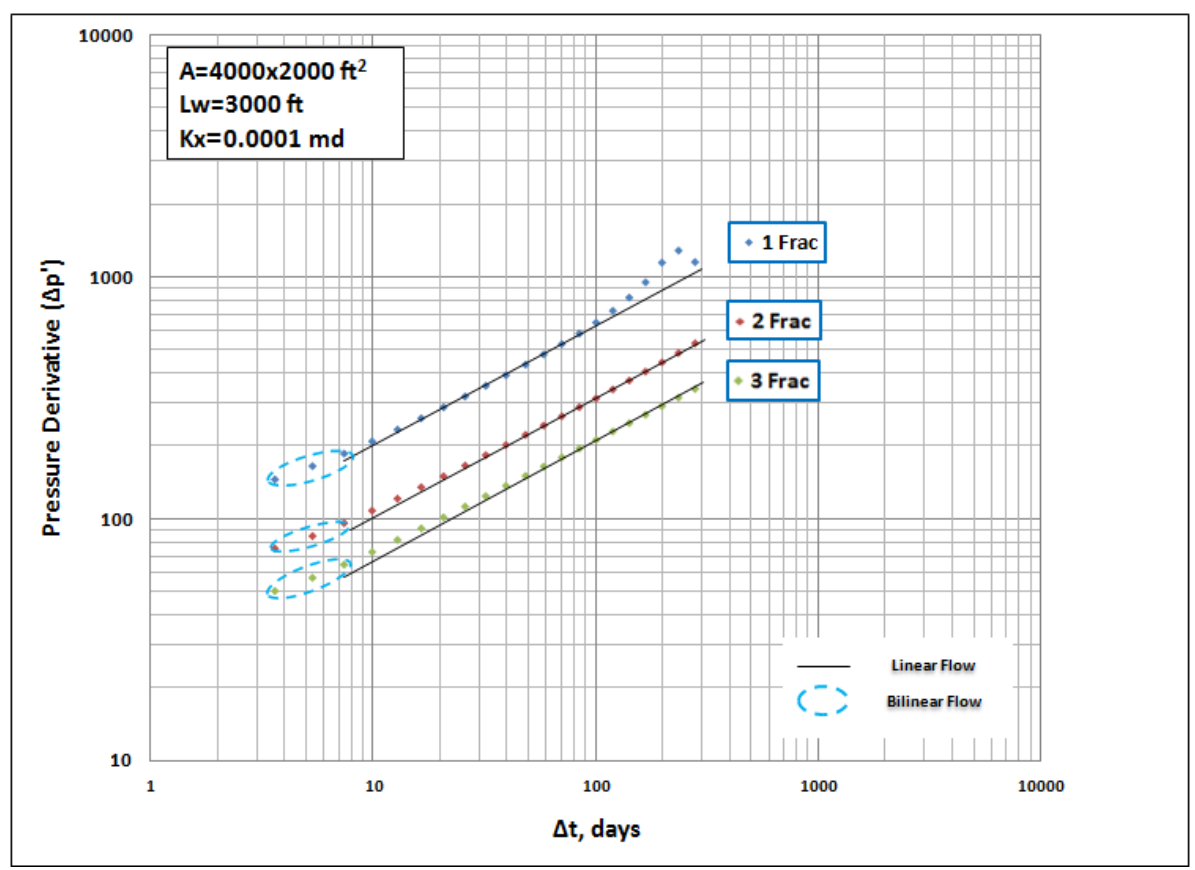

Figure 19: The impact of fracture width $\left(\mathrm{w}_{\mathrm{f}}=0.01\right.$ inch $)$ 


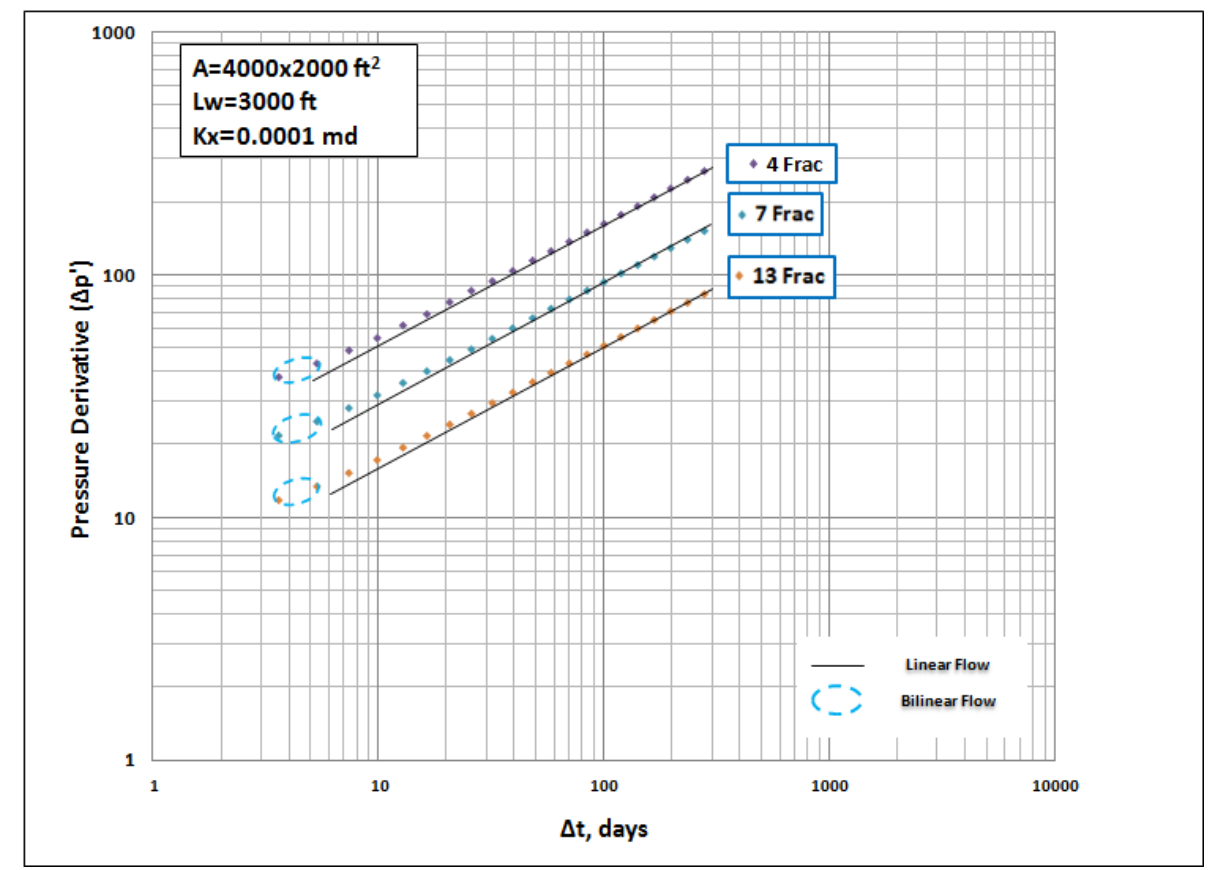

Figure 20: Impact of fracture width $\left(w_{\mathrm{f}}=0.01\right.$ inch $)$

\subsection{The Impact of Drainage Area and Horizontal Well Length on Flow Regimes}

The purpose of these runs is to investigate the second linear flow as shown in Figure 21 through Figure 24. The appearance of the second linear flow is not caused by the outer regions because the extent of the horizontal well is the same as the length of the drainage area and the extent of the fracture length is the same as the width of the drainage area. Therefore, one linear flow was perpendicular to the fracture while the other one was parallel to the fracture or perpendicular to the horizontal well. In Figure 21 through Figure 24, it is found that the second linear flows appear in the cases where the fracture numbers are less than four. When the number of fractures becomes more than four, the spacing between the fractures comes closer and only one linear flow is observed. 


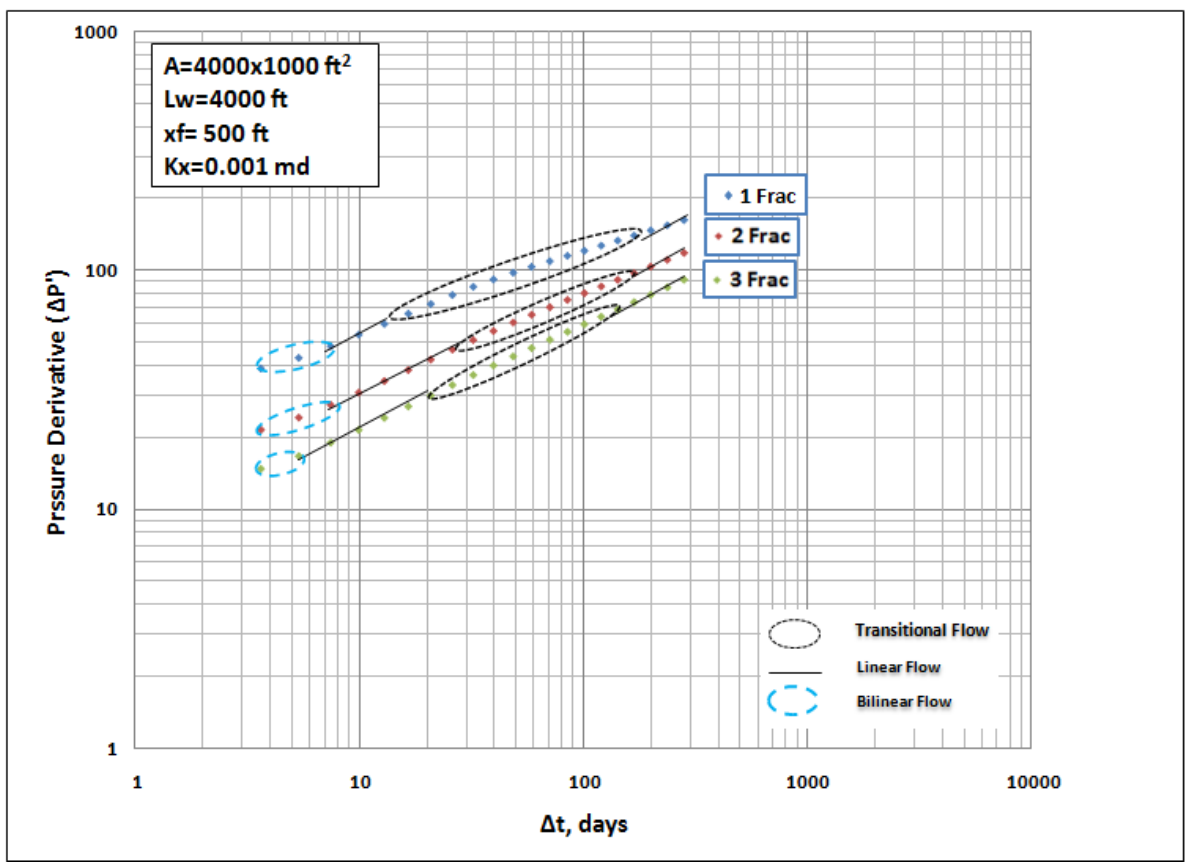

Figure 21: The impact of drainage area and horizontal well length $\left(w_{\mathrm{f}}=0.1\right.$ inch $)$

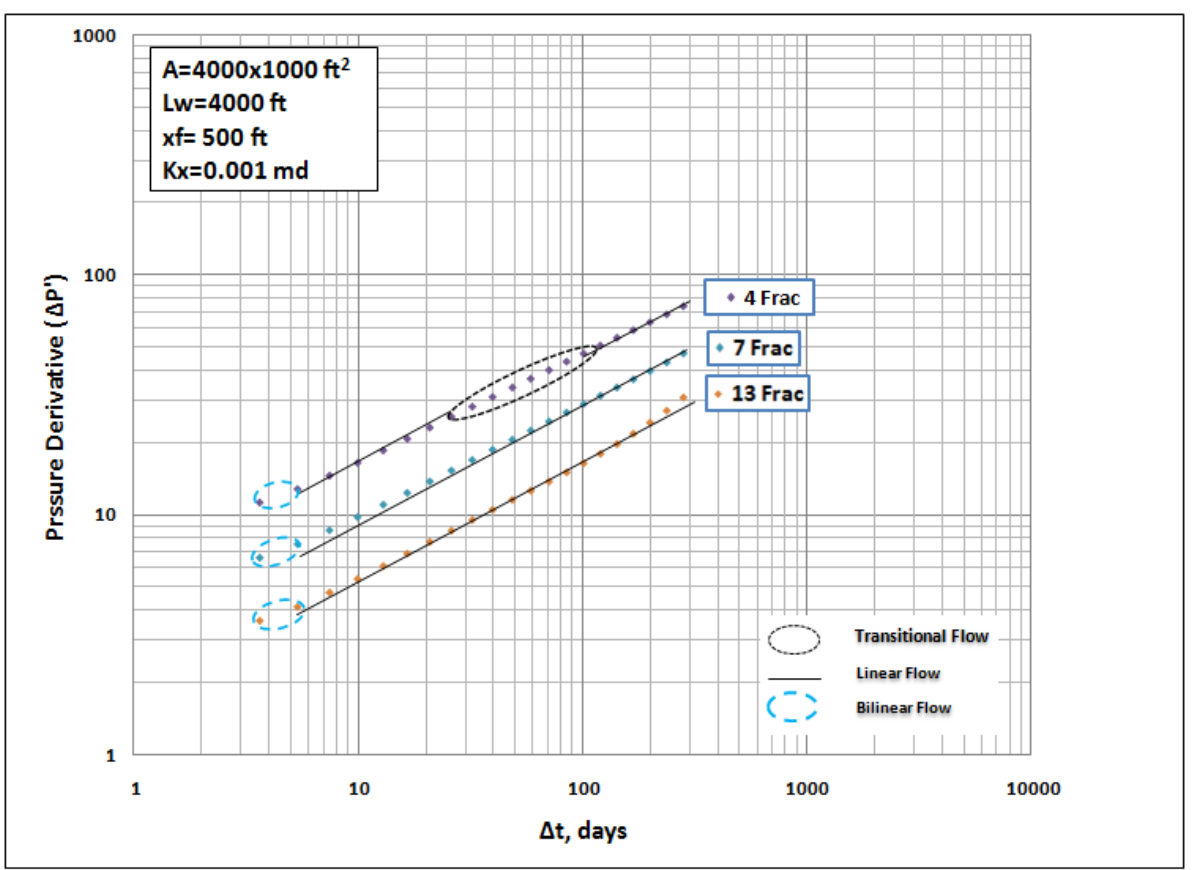

Figure 22: The impact of drainage area and horizontal well length $\left(w_{f}=0.1\right.$ inch $)$ 


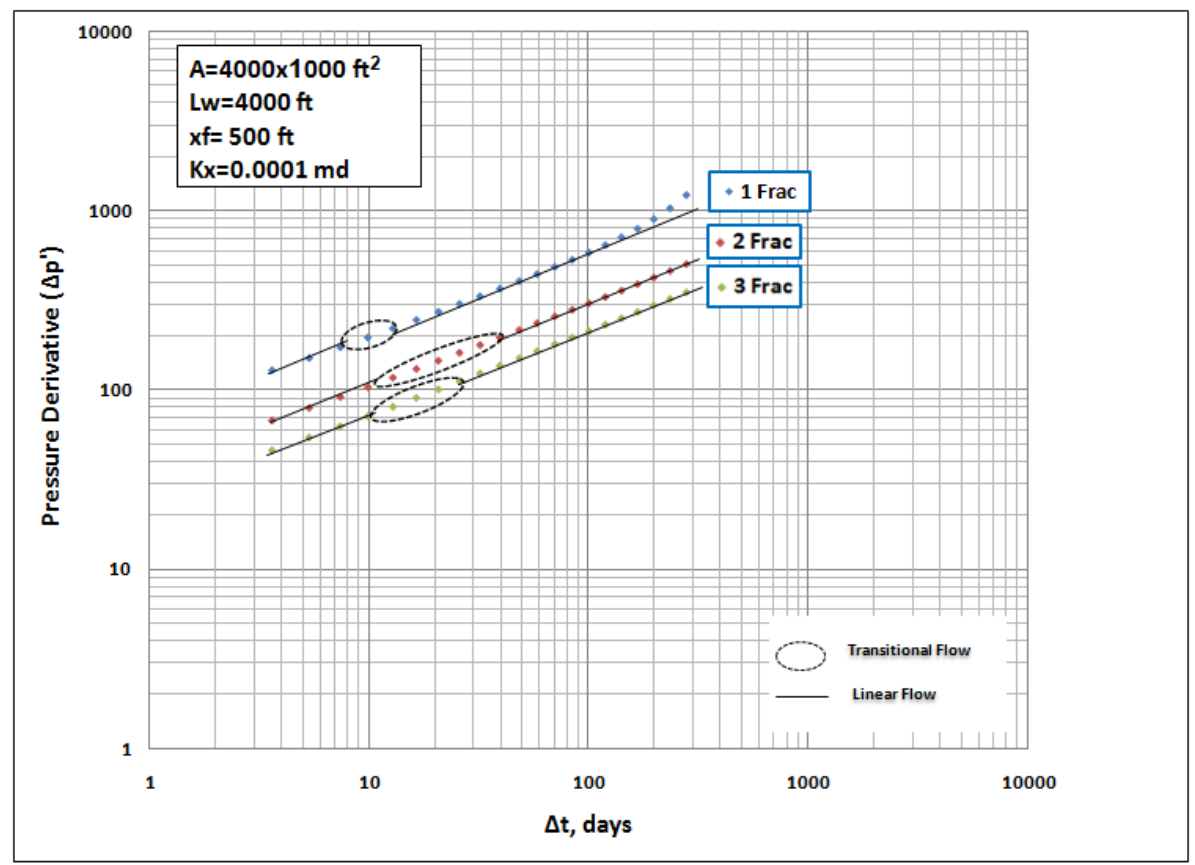

Figure 23: The impact of drainage area and horizontal well length $\left(w_{\mathrm{f}}=0.1\right.$ inch)

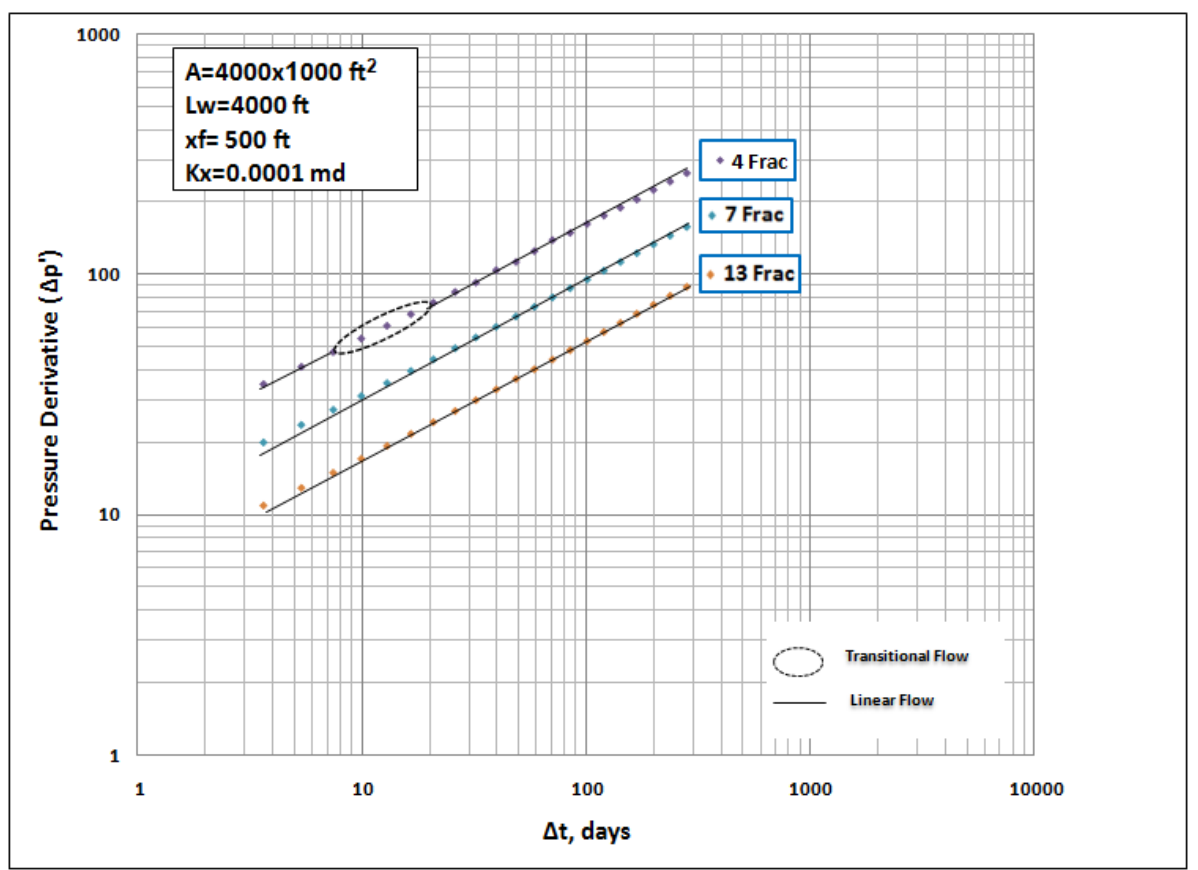

Figure 24: The impact of drainage area and horizontal well length $\left(\mathrm{w}_{\mathrm{f}}=0.1\right.$ inch) 


\subsection{The Impact of Fracture Permeability on Flow Regimes}

The fracture permeability was varied into two values $-10,000 \mathrm{md}$ and $40,000 \mathrm{md}$. It was found that the fracture permeability has no impact on flow regimes. Figure 25 and Figure 26 are plotted for four and thirteen hydraulic fractures and no effect of the fracture permeability on flow regimes was observed.

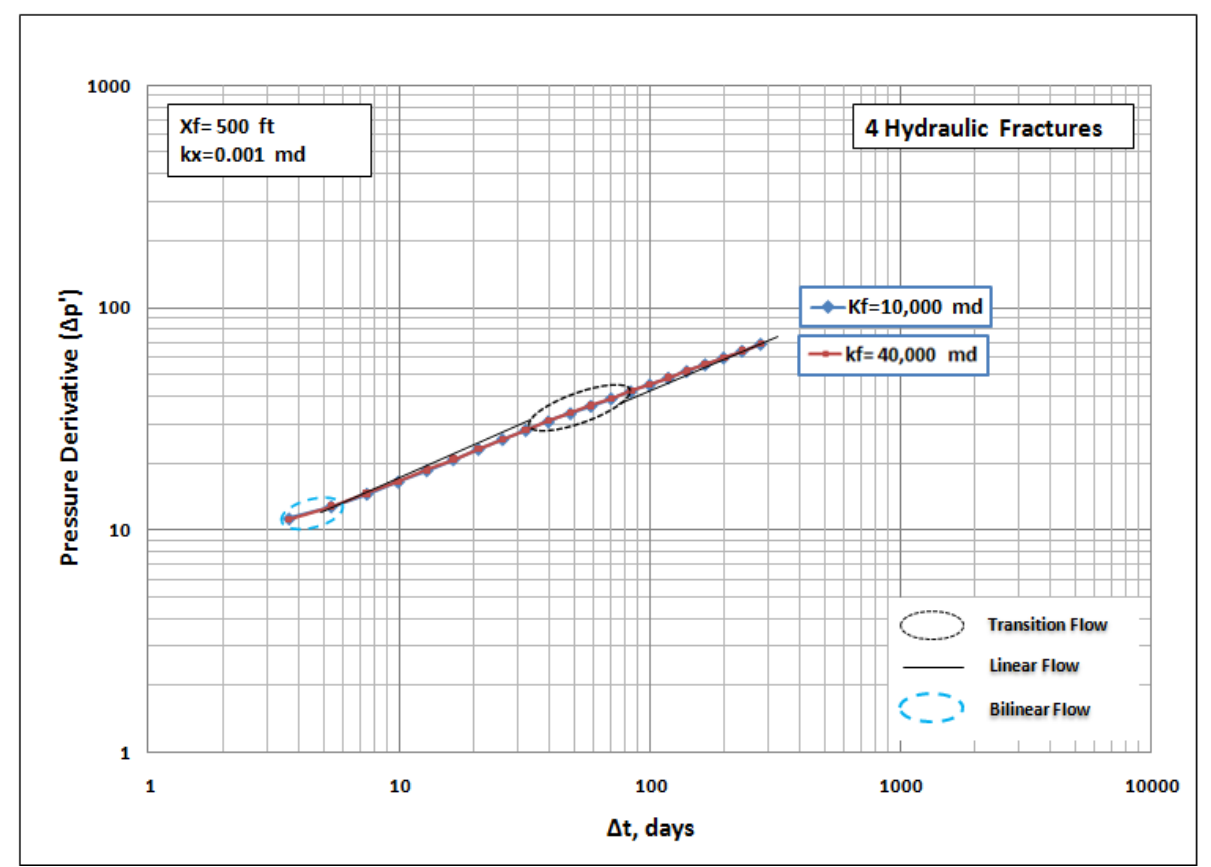

Figure 25: The impact of fracture permeability for 4 hydraulic fractures. 


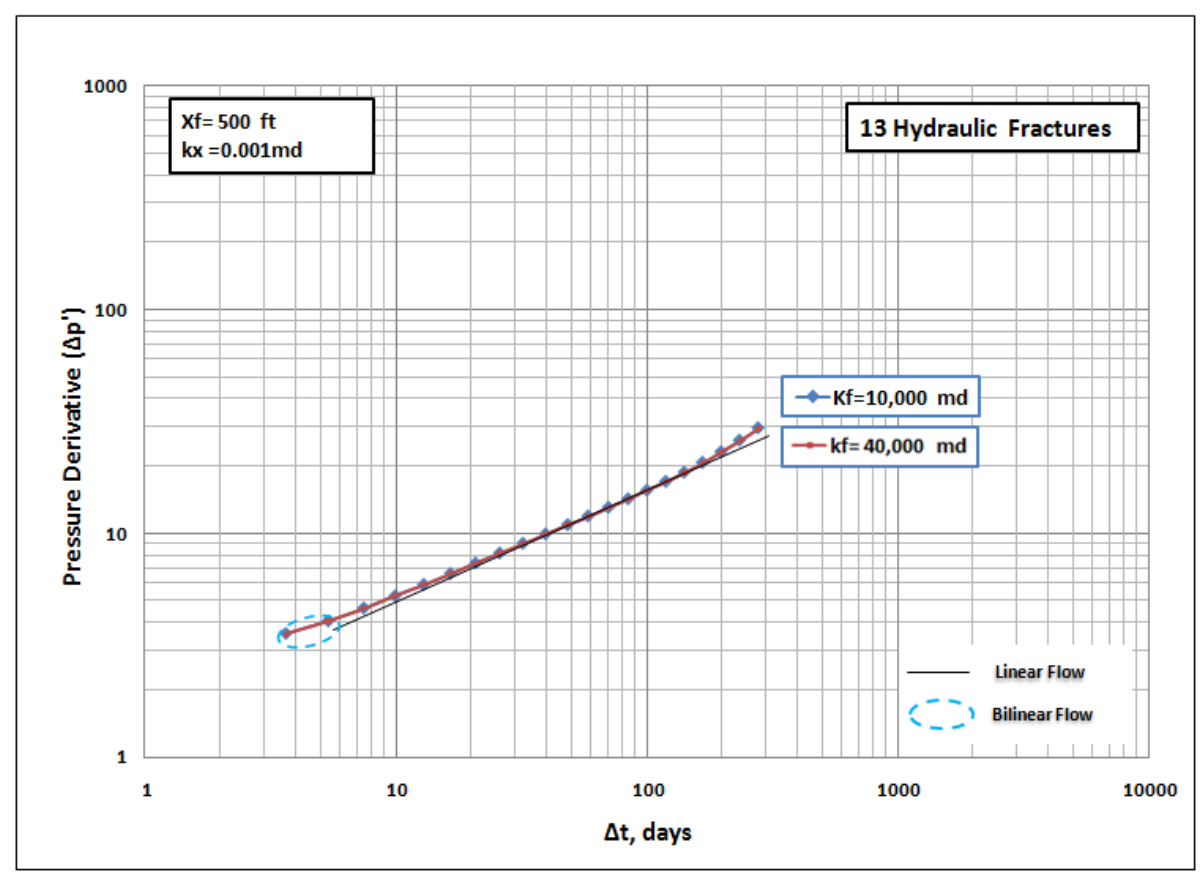

Figure 26: The impact of fracture permeability for 13 hydraulic fractures

\subsection{The Impact of Fracture Half Length on Flow Regimes}

Figure 27 and Figure 28 illustrate the impact of fracture half length on flow regime; these figures explain that at a lower number (e.g. four) of hydraulic fractures, the same type of flows is observed for both fracture half lengths. However, at a higher number of fractures (e.g. thirteen), lower fracture half length exhibits two linear flows whereas at a higher fracture half length two linear flows overlap each other and become one linear flow. 


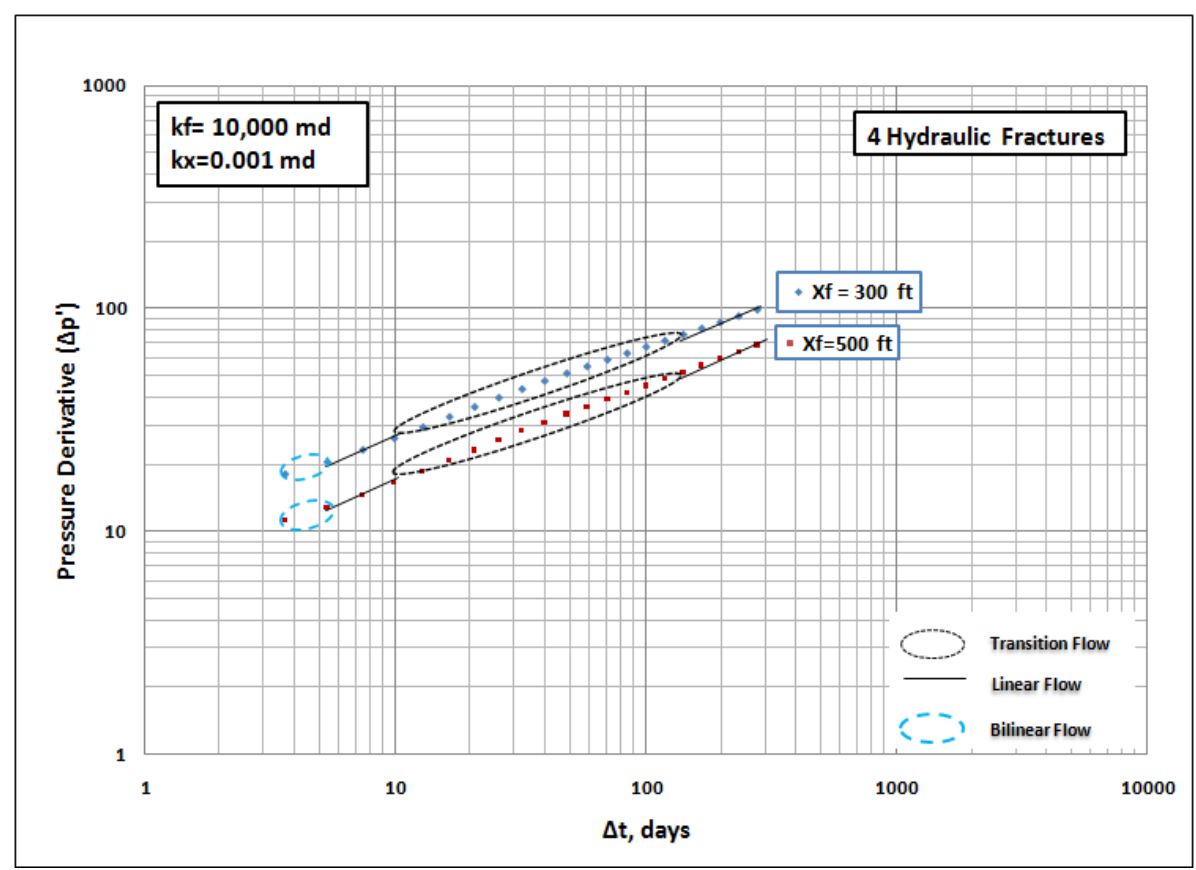

Figure 27: The impact of fracture half length for $\mathbf{4}$ hydraulic fractures

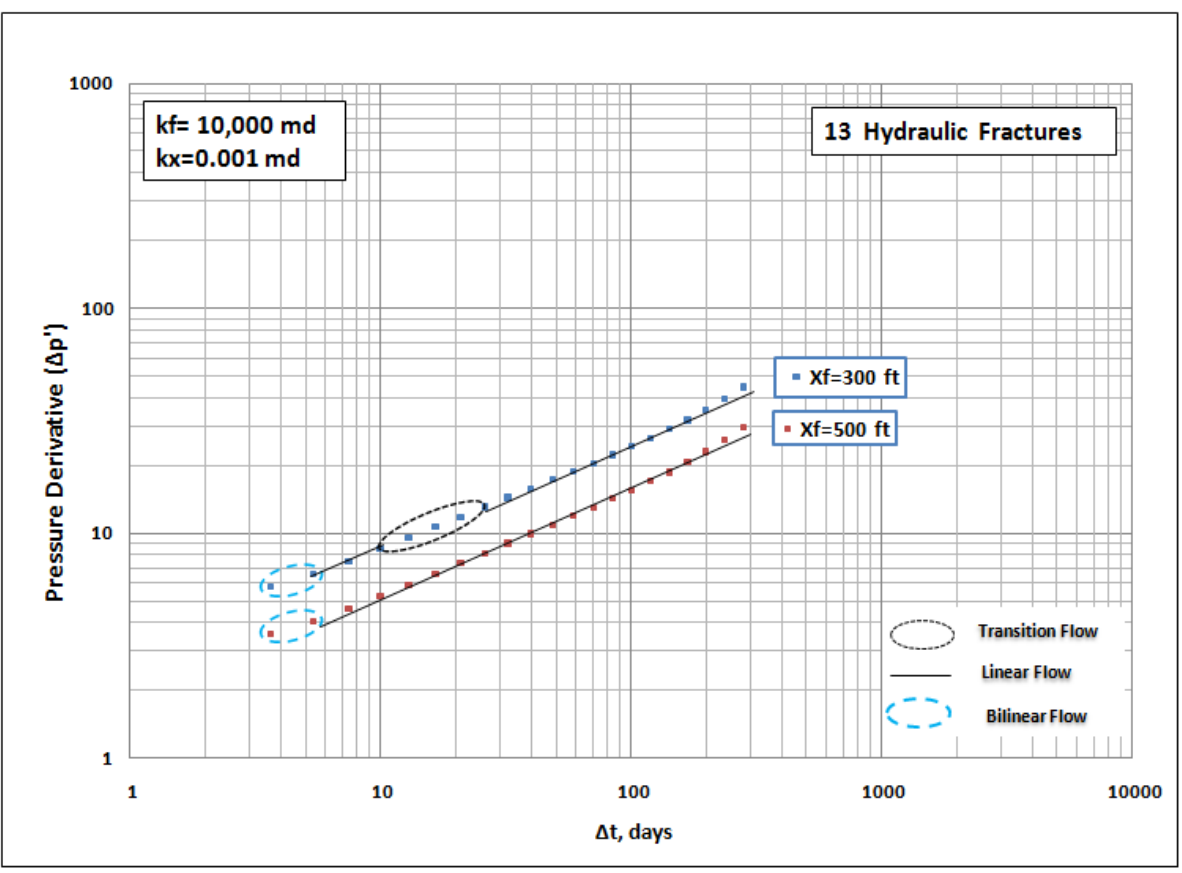

Figure 28: The impact of fracture half length for 13 hydraulic fractures 


\subsection{The Impact of Fracture Porosity on Flow Regimes}

Figure 29 and Figure 30 show that there is no effect of fracture porosity on flow regimes with different numbers of hydraulic fractures as the curves with different fracture porosity coincide with each other. The values range used for fracture porosity is shown in figure 29 .

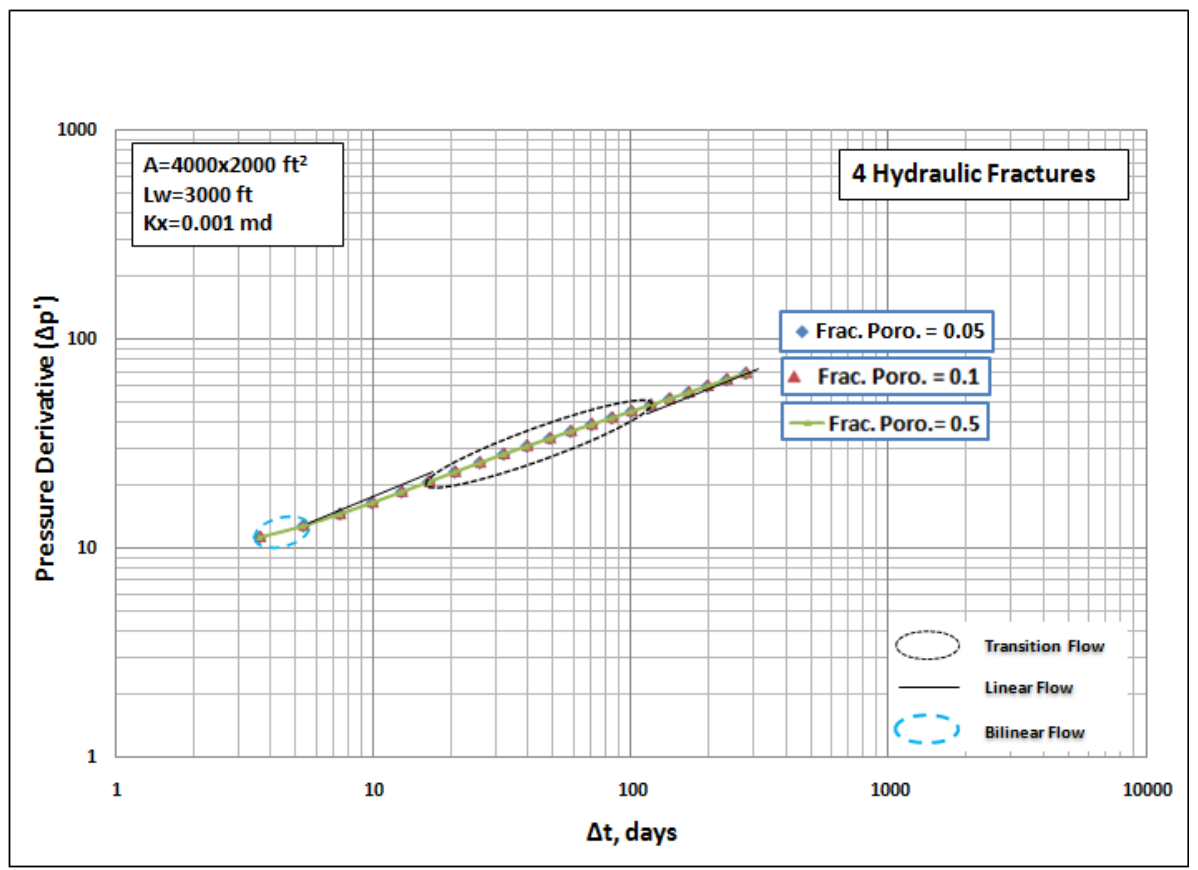

Figure 29: The impact of fracture porosity for $\mathbf{4}$ hydraulic fractures 


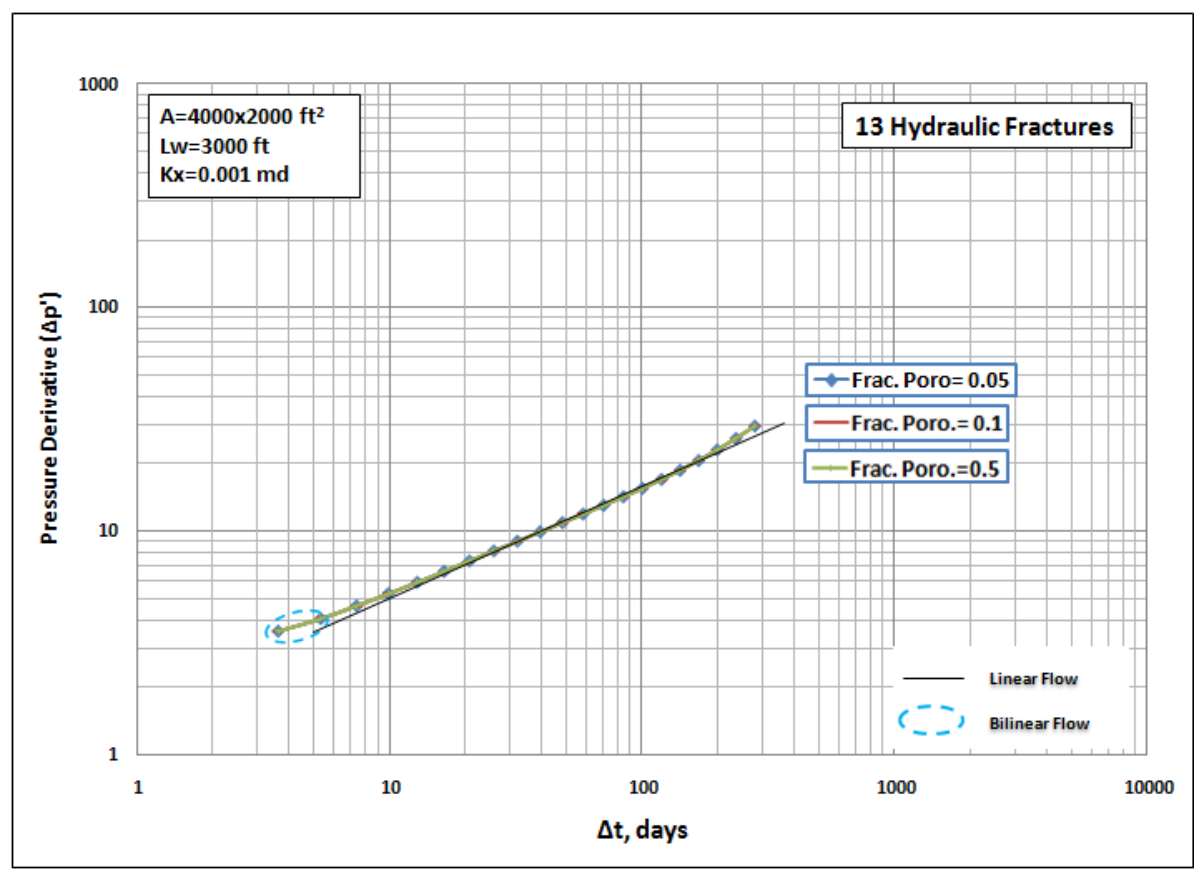

Figure 30: The impact of fracture porosity for $\mathbf{1 3}$ hydraulic fractures 


\section{CHAPTER 5}

\section{CONCLUSIONS}

The objective of this research was to understand the pressure transient responses from horizontal wells with multiple hydraulic fractures. In addition, the impact of the reservoir and fracture properties in horizontally fractured wells on flow regimes in low permeability was also studied. Based on the results, the following conclusions were made:

1. Different flow regimes are observed, the fracture-radial flow, bilinear flow, linear flow and Compound linear flow.

2. The fracture radial flow appears with the decrease in fracture width.

3. The horizontal wells with a higher number of hydraulic fractures exhibit a longer linear flow period than those wells with a fewer number of hydraulic fractures.

4. Permeability and porosity of the hydraulic fracture do not have any significant impact on the flow regimes.

5. Drainage area and horizontal well length have a significant effect on flow regimes with a higher number of hydraulic fractures. When the extent of the horizontal well is equal to the length of the drainage area and the extent of the fractures is equal to the width of the drainage area, two linear flows become one linear flow at a higher number of hydraulic fractures.

6. The increase in the number of hydraulic fractures results in the two linear flow to become one linear flow.

7. With the decrease in the permeability of the reservoir, bilinear flow tends to disappear, because of the increase in the fracture conductivity 


\section{NOMENCLATURE}

$F_{c d}=$ Dimensionless Fracture Conductivity

$\mathrm{h}=$ Reservoir thickness, $\mathrm{ft}$

$\mathrm{k}=$ Reservoir permeability, md

$\mathrm{k}_{\mathrm{f}}=$ Fracture permeability, md

$\mathrm{K}_{\mathrm{x}}=$ Reservoir permeability in X-direction, $\mathrm{md}$

$K_{y}=$ Reservoir permeability in Y-direction, md

$K_{z}=$ Reservoir permeability in Z-direction, $\mathrm{md}$

$L=$ Reservoir Length, $\mathrm{ft}$

$L_{w}=$ Horizontal well length, $\mathrm{ft}$

$P_{w \mathrm{f}}=$ Wellbore pressure, psia

$P_{i}=$ Initial reservoir pressure, psia

$s=$ Skin factor

$\Delta t=$ Time, days

$T c f=$ Trillion cubic feet

$W=$ reservoir width, $\mathrm{ft}$

$w_{f}=$ Fracture width, $\mathrm{ft}$

$x_{f}=$ Fracture half length, $\mathrm{ft}$

$\Delta \mathrm{P}=$ Pressure change, $\mathrm{psia}$

$\Delta \mathrm{P}{ }^{\prime}=$ Pressure derivative 


\section{REFERENCES}

Aminian, K., Lecture 4, Pressure Transient Analysis. Morgantown: West Virginia University, 2009.

Brown, M., and Ozkan, E., Colorado School of Mines; Raghavan, R., Phillips Petroleum Co. (Retd.); and Kazemi, H., Colorado School of Mines. "Practical Solutions for Pressure Transient Responses of Fractured Horizontal Wells in Unconventional Reservoirs". SPE 125053, paper presented at the 2009 SPE Annual Technical Conference and Exhibition, New Orleans, Louisiana,, USA, 4-7 Octaober2009.

Daniel Arthur, J., Brian Bohm, Bobbi Jo Coughlin, and Mark Layne, ALLConsulting. "Evaluating the Environmental Implications of Hydraulic Fracturing in Shale Gas Reservoirs". SPE 121038, paper presented at the 2009 SPE Americas E\&P Environmental \& Safety Conference, San Antonio, Texas, USA, 23-25 March 2009.

Eclipse Reservoir Engineering Software Manual. 2010 Schlumberger.

Ground Water Protection Council, Oklahoma City and ALL Consulting, Tulsa, (April, 2009). "Modern Shale Gas Development in the United States: A Primer", Prepared for U.S. Department of Energy Office of Fossil Energy and National Energy Technology Laboratory. http://www.netl.doe.gov/technologies/oil-gas/publications/epreports/shale gas primer 2009.pdf

Joshi, S.D., Horizontal Well Technology, OK: Penn Well Books, 1991.

Larsen, Leif, Statoil A/S, and Hegre, T.M., Petec A/S. "Pressure-Transient Analysis of Multifractured Horizontal Wells." SPE 28389, paper presented at the SPE $69^{\text {th }}$ Annual Technical Conference and Exhibition, New Orleans, LA, USA, 25-28 Sep. 1994.

Lee, J. and Wattenbarger, R. A., "Gas Reservoir Engineering”, TX: SPE Textbook Series vol. $5,(1996)$.

Marcellus Shale - Appalachian Basin Natural Gas Play, http://geology.com/articles/ marcellusshale.shtml, Download March 26, 2011.

Medeiros, F., Petroas, Kurtoglu B., Ozkan E., and Kazemi H. "Pressure-Transient Performance of Hydraulically Fractured Horizontal wells in Locally and Globally Naturally Fractured Formations," IPTC 11781, paper presented at the International Petroleum Technology Conference, Dubai, U.A.E., Dec. 4-6, 2007.

Naik, G.C, "Tight Gas Reservoirs- an Unconventional Natural Energy Source for Future," www.pinedaleonline.com/socioeconomic/pdfs/tight_gas.pdf, Download March 25, 2011, p. 23.

Ozkan, E., Al-Kobaisi, M., Kazemi, H., Ramirez, B. Colorado School of Mines(PETSOC 2006-162). "Pressure Transient Analysis of Fractured Horizontal Wells withTransverse, Finite 
Conductivity Fractures. Paper presented at the petroleum Society's $7^{\text {th }}$ Canadian International Petroleum Conference, Calgary, Alberta, Canada, June 13-15, 2006.

Thakur, G. C., Chevron Petroleum Technology Company "Horizontal Well Technology- A key to Improving Reserves," Journal of Canadian Petroleum Technology, October 1999, Volume 38, No. 10, pp. 99-10-05.

Schlumberger Wireline \& Testing, "Introduction to Well Testing”, Bath, England. March 1998.

Zammerilli, Anthony M.. "Projecting the Economic Impact of Marcellus Shale Gas Development in West Virginia: A Preliminary Analysis Using Publicly Available Data" Prepared for National Energy Technology Laboratory. March 31, 2010. http://www.iogawv.com/pdfs/WVMarcellusEconomics3.pdf 